\title{
The Effect of Dialectical Behavior Therapy Techniques Training with lavender Aromatherapy on Depression and Maternal Competence of Nulliparous Women with Insecure Attachment to Spouse
}

\author{
Elham Zameni $^{1}$ (D), Fatemeh Shahabizadeh ${ }^{2 *(D)}$, Jalil Jarahi Feriz ${ }^{3}$ (D), Nahid Ghanbarzadeh ${ }^{3,4}$ (D)
}

1. PhD Student in Psychology, Department of Psychology, Birjand Branch, Islamic Azad University, Birjand, Iran

2. Associate Professor, Department of Psychology, Birjand Branch, Islamic Azad University Birjand, Iran

3. Assistant Professor, Department of Psychology, Birjand Branch, Islamic Azad University, Birjand, Iran

4. Department of Obstetrics and Gynecology, Birjand University of Medical Sciences, Birjand, Iran

\begin{tabular}{|c|c|}
\hline Article Info & ABSTRACT \\
\hline $\begin{array}{l}\text { Received: 2021/05/29; } \\
\text { Accepted: 2021/08/21; } \\
\text { Published Online: } 2021 / 12 / 21\end{array}$ & $\begin{array}{l}\text { Introduction: Pregnancy is one of the most stressful stages in Women's life. The purpose } \\
\text { was to determine the effectiveness of Dialectical Behavior Therapy Techniques Training } \\
\text { lavender aromatherapy on depression and maternal competence of Primiparous women with } \\
\text { Insecure Attachment to Spouse. }\end{array}$ \\
\hline
\end{tabular}

10.30699/ajnmc.29.4.314

Original Article

Use your device to scan and read the article online

Methods: This clinical trial study was performed in 2021 on 60 pregnant women in Birjand, Iran. Insecure attached expectant mothers were selected by purposive sampling method and randomly divided between three intervention groups 1 (Dialectical behavior therapy techniques training and aromatherapy), intervention group 2 (aromatherapy with lavender), and control group. Dialectical behavioral therapy techniques were performed in the last three months of pregnancy, aromatherapy in the active phase of labor, and the follow-up period one month after the baby's birth. The attachment to spouse Questionnaire, depression Beck, postpartum depression, and maternal competency were used. Data were analyzed in SPSS 25.

Results: The results of repeated analysis of variance showed that teaching dialectical behavioral therapy techniques was effective in reducing depression over time $(P<0.001)$. Covariance analysis showed that depression during pregnancy was decreased significantly after the Dialectical Behavior Therapy Techniques Training $(P<0.001)$. The multivariate analysis of variance also showed both components of maternal competence increased significantly in intervention groups $1(P<0.05)$.

Conclusion: Dialectical behavioral therapy techniques and aromatherapy are effective interventions to reduce depression and increase maternal competence. They can be used for pregnant women with insecure attachment to their husbands in health centers.

Keywords: Dialectical behavioral therapy, Aromatherapy, Lavender, Attachment, Depression, Competency

Corresponding Information:

Fatemeh Shahabizadeh, Associate Professor, Department of Psychology, Birjand Branch, Islamic Azad University Birjand, Iran. Email: $\underline{\text { f shahabizadeh@yahoo.com }}$

Copyright $\odot$ 2021, This is an original open-access article distributed under the terms of the Creative Commons Attribution-noncommercial 4.0 International License which permits copy and redistribution of the material just in noncommercial usages with proper citation.

\section{How to Cite This Article:}

Zameni E, Shahabizadeh F, Jarahi Feriz J, Ghanbarzadeh N. The Effect of Dialectical Behavior Therapy Techniques Training with lavender Aromatherapy on Depression and Maternal Competence of Nulliparous Women with Insecure Attachment to Spouse. Avicenna J Nurs Midwifery Care. 2021; 29 (4) :314-327 
اثربخشى آموزش فنون رفتاردرمانى ديالكتيك توأم با رايحهدرمانى اسطوخودوس بر افسردَى و شايستغى

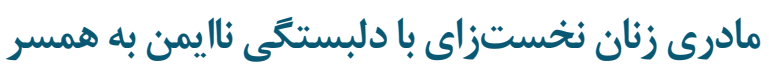

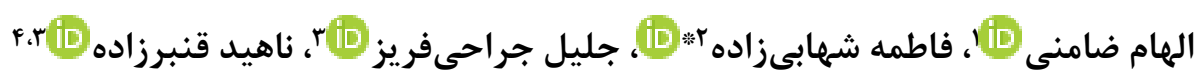

ا. دانشجوى دكترى روان شناسى، واحد بيرجند، دانشگاه آزاد اسلامى، بيرجند، ايران

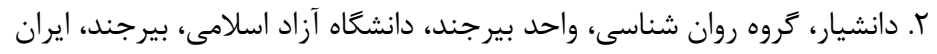

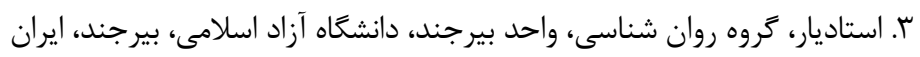

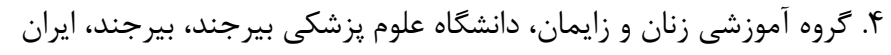

\begin{tabular}{|c|c|}
\hline جكيده & 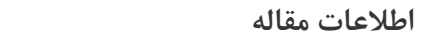 \\
\hline 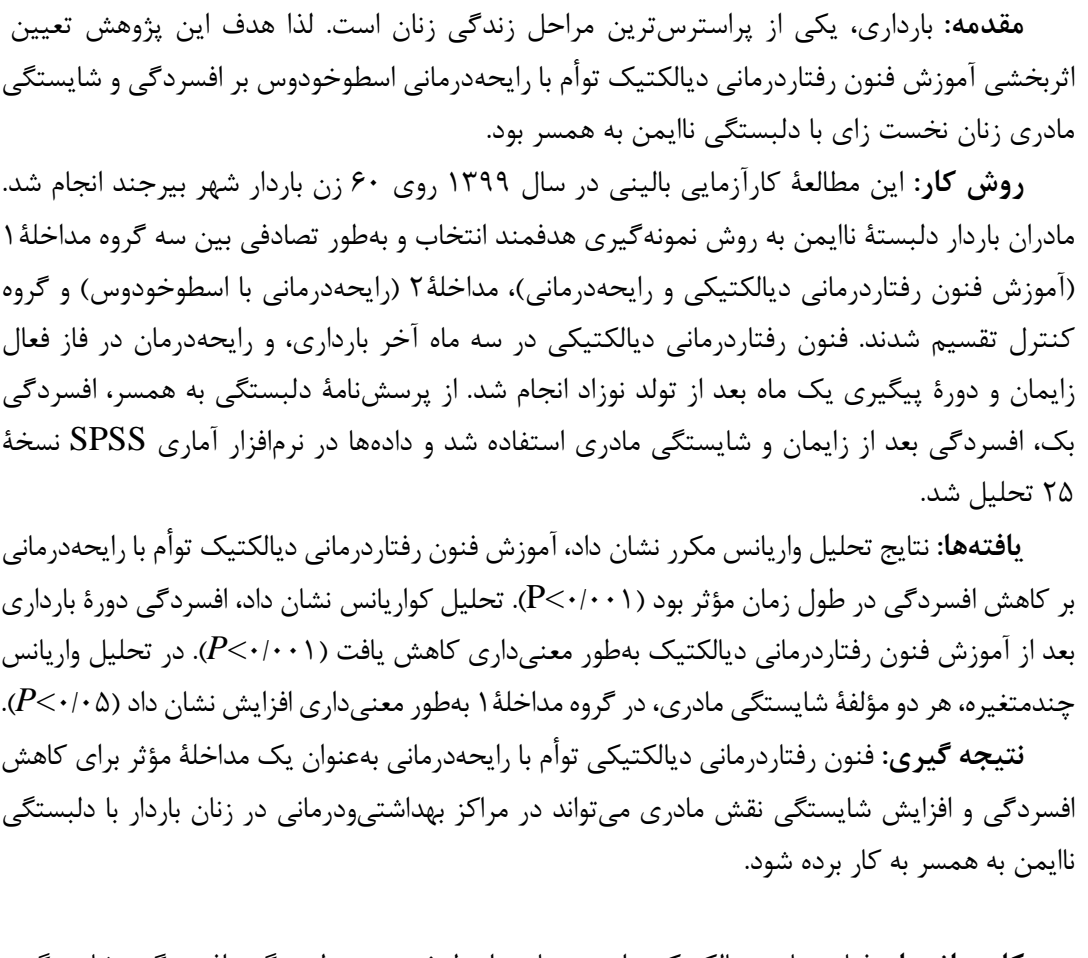 & 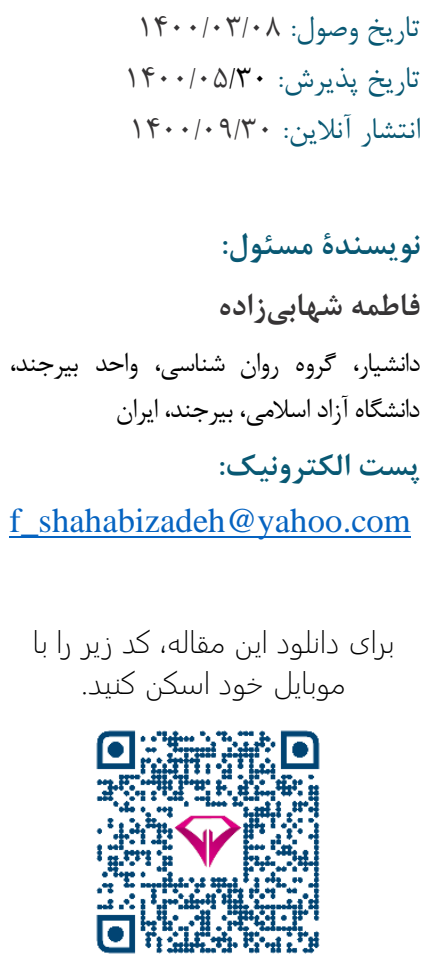 \\
\hline كليدوازهها: رفتاردرمانى ديالكتيك، رايحهدرمانى، اسطوخودوس، دلبستخى، افسردگى، شايستگى & \\
\hline
\end{tabular}

مقدمه

بهعنوان بزرگترين نخرانى بهداشتى در قرن بيست و يكم

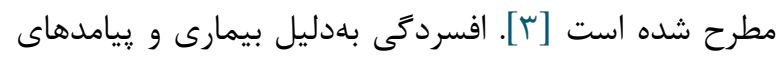

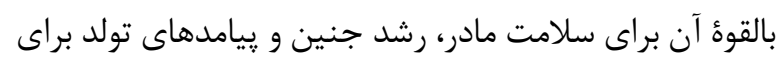

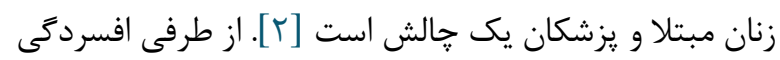

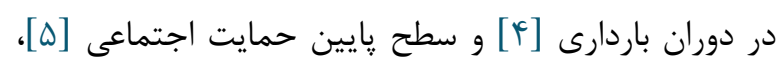
ييشبينى كننده قوى افسردكى يس از زايمان است [r] است،

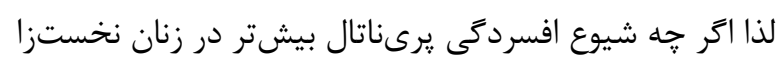
و در سه ماهُ سوم باردارى، درست قبل از زايمان به اوج خود
باردارى يكى از يرتنشترين رويدادهاى زندگى زنان است

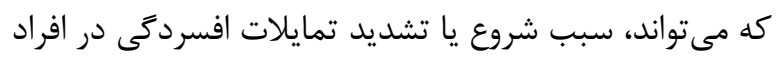

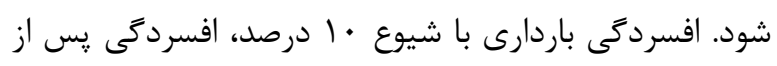

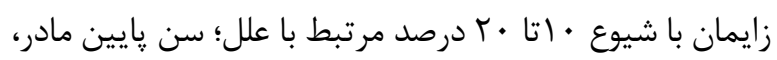

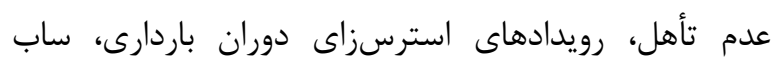

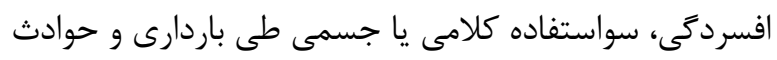

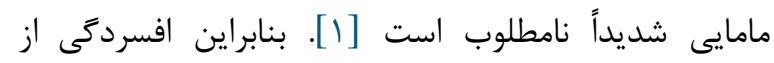

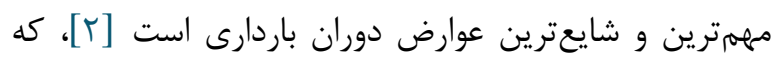


بركهاى باريك، كه عمدتاً نواحى مديترانهاى، آمريكاى شمالى

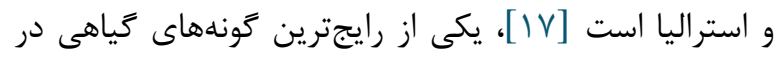

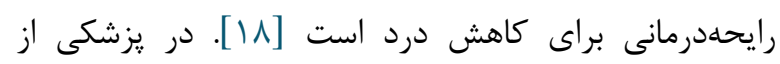
اسطوخودوس بهعنوان ضد اضطراب [19]، آرامبخش، مخدر، ضد التهاب و ضد افسردى استفاده مىشود [r [r]. در مطالعات

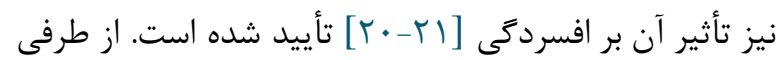

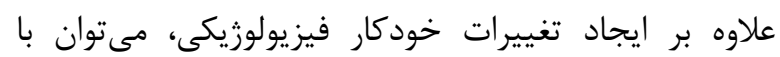

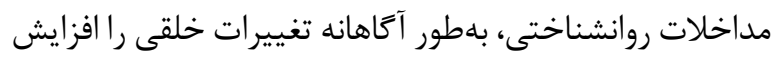

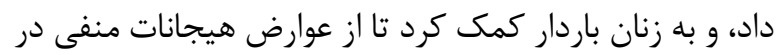

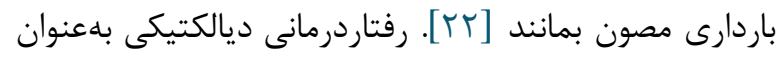

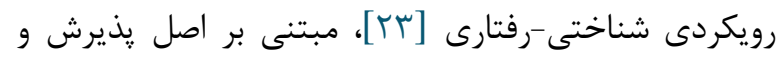

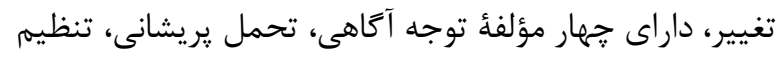

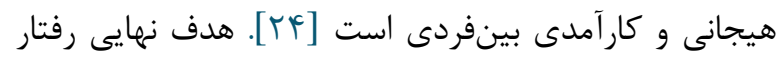

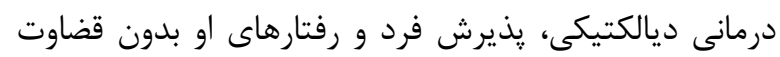

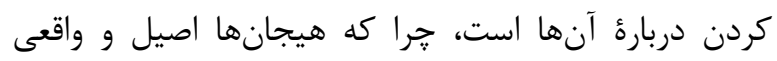
هستند و بهطور مكرر تجربه مىشوند، اما مى توان واكنش به إنها

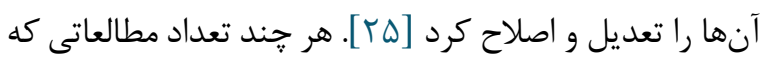

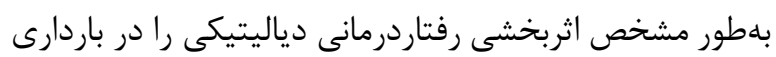
بررسى كردهاند، محدود است، اما در مطالعاتى كه اثربخشى إنى

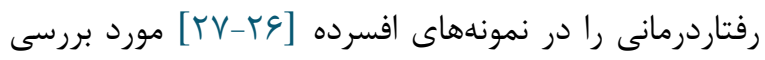

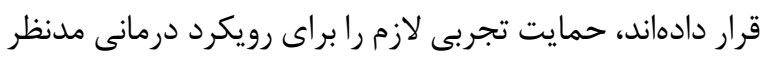

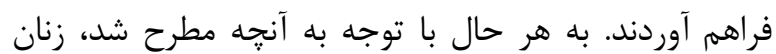

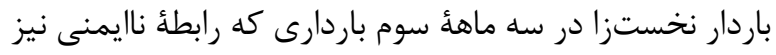

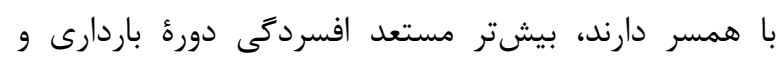

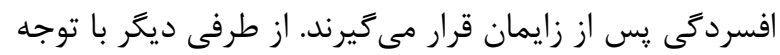
به اينكه مدت زيادى از كاربرد رفتار درمانى دياليتيكى فردي

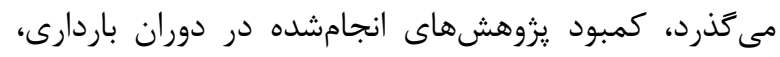
بهوطور جدى احساس مى شودن. بنابر اين هدف اين يزوهش، تعيين اثربخشى آموزش فنون

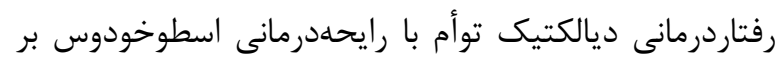

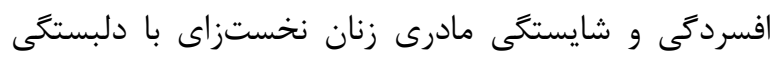

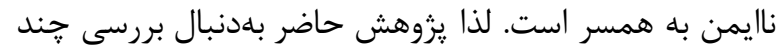

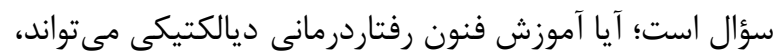

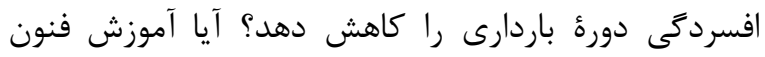
رفتاردرمانى ديالكتيكى با رايحهدرمانى مى تواند افسردكى يس

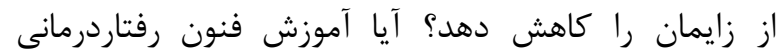

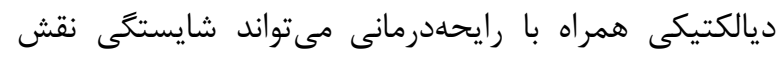

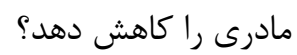

مىرسد [9]، اما حمايت و دلبستگى به همسر مىتواند تعديل كنندة اثرات منفى افسردىى دوران باردارى باشد و داندان

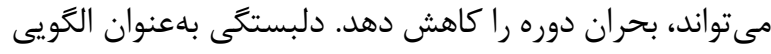

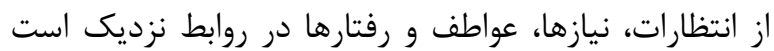

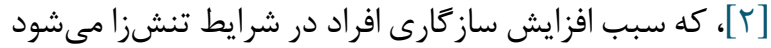

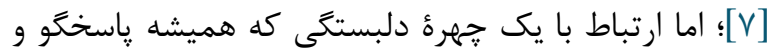

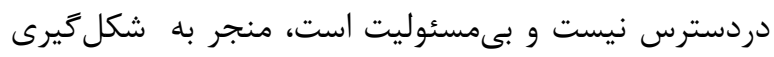

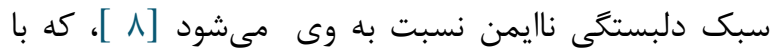
تجربه هيجانات منفى و استفاده از راهبردهاى نافعال سازى يا لنائ

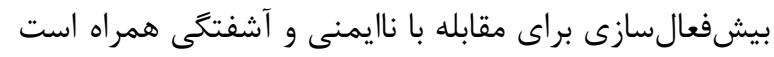

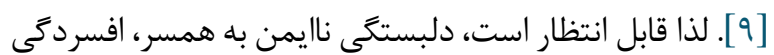

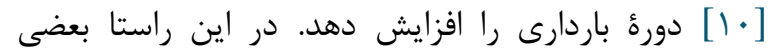

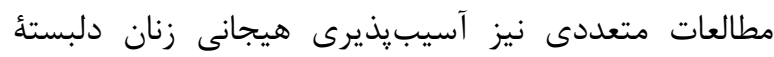

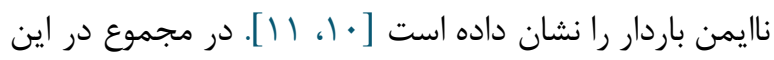
مطالعه، زنان باردار نخستزا در سه ماهؤ سوم باردارى كه احتمال داشت، بيشتر در معرض آسيبهاى افسردگى باشند،

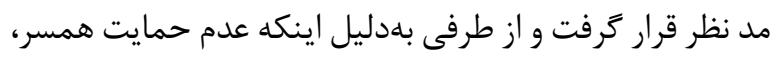

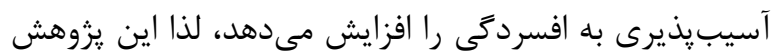
بهدنبال بررسى زنان باردار نخستزايى است كه دلبستگى نايمن به همسر داشتند. از طرفى آسيبهاى هيجانى و علائم افسردىى پس از زايمان سبب تعاملات منفى مادر و نوزاد

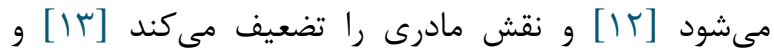
زمينهساز مشكلات رفتارى كودى در آينده مىشود [1]. به ماديه

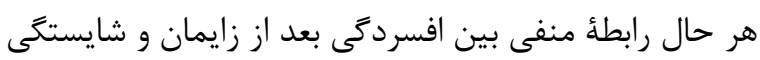
نقش مادرى تأييد شده است [1F] شايستگى نقش مادرى تعاملى دوسويه وجود دارد كه حمايت

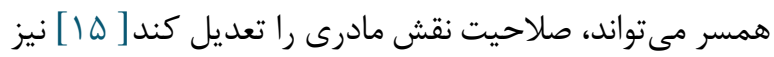

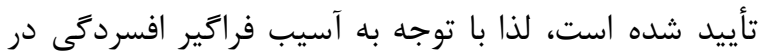

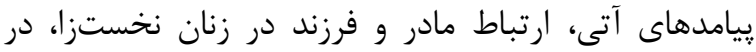

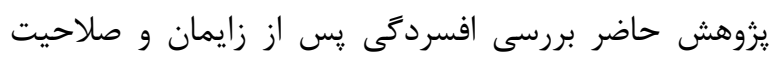

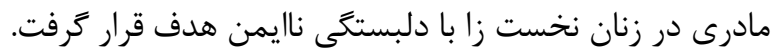
از سويى تجربؤ درد زايمان مى تواند پِيامدهاى منفى براى نقش مادرى در بعد از زايمان داشته باشد، بنابراين بنا به

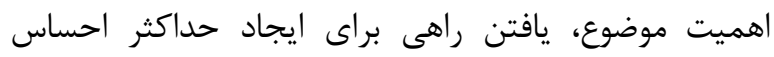
تسكين درد و آرامش، با حداقل عوارض، يكى از مههمترين

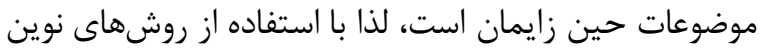

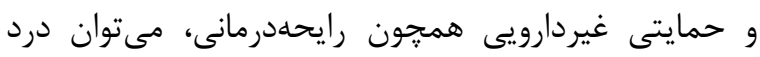

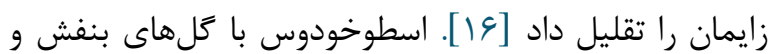


خروج از مطالعه شامل؛ هركونه اختلال در روند باردارى مانند

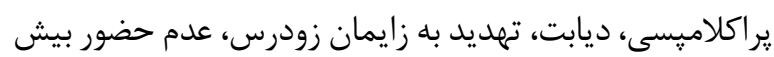
از r جلسه و ختم باردارى با سزارين بود.

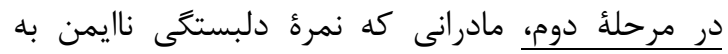

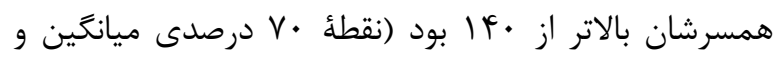

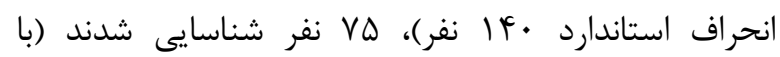

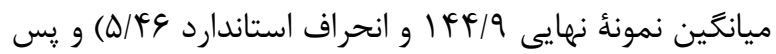
از كسب رضايتنامةٔ كتبى، هر كدام از مادران بهصورت تصادفى ندانى

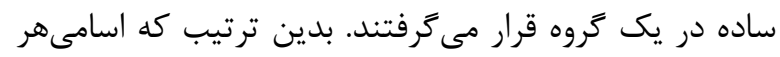

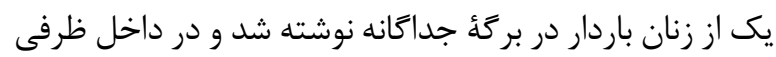

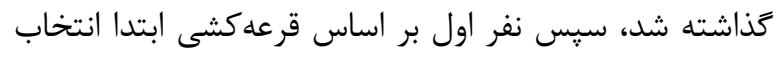

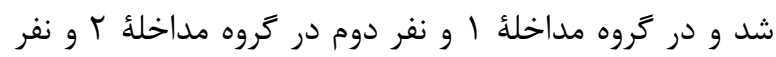

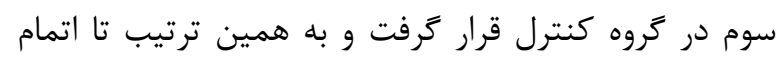

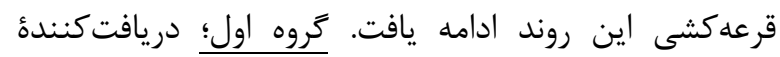

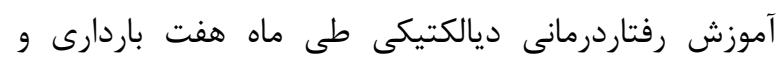

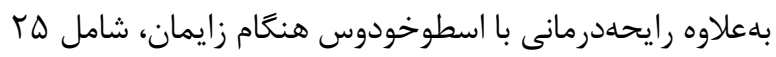

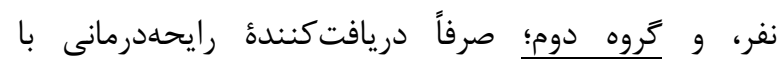

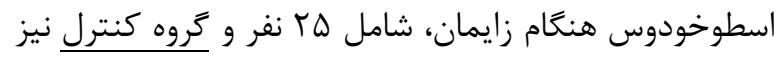

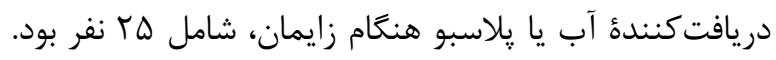

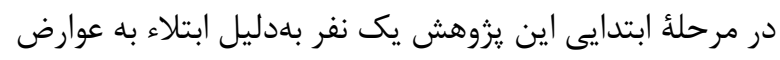

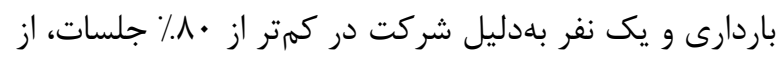

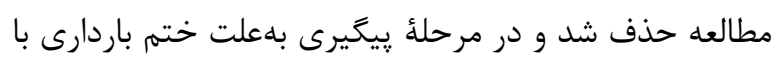

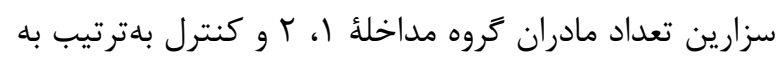
9 19، آ و •r نفر تقليل يافت.

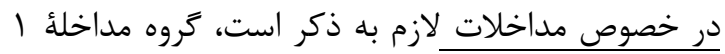

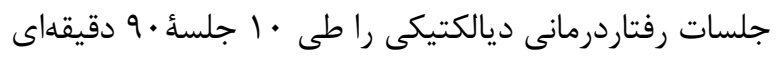

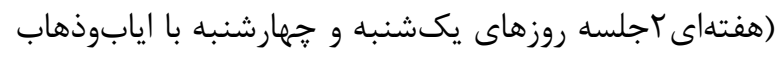
توسط يزوهشكر) در ه هفته توسط يزوهشكر در ساختمانى رونى

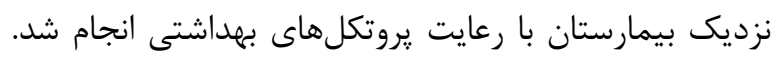

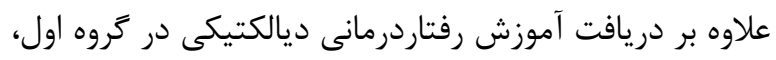

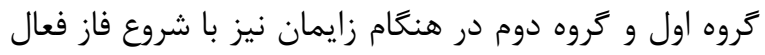

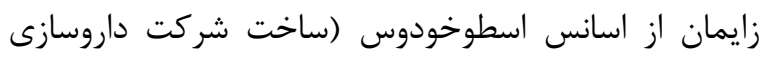

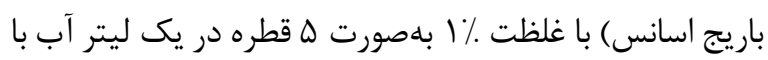

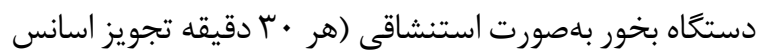

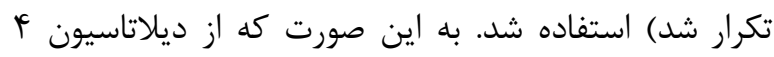

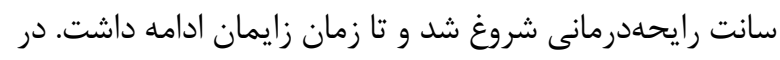
بين هر نيم ساعت، ريختن اسانس اسطوخودودس در دستخاه
روش كار

يزوهش حاضر به شكل كارآزمايى بالينى، روى زنان باردار

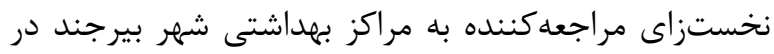

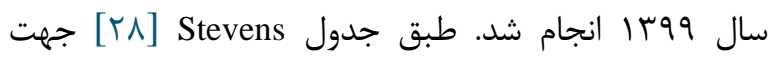

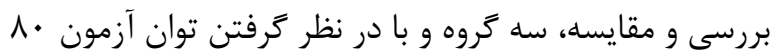

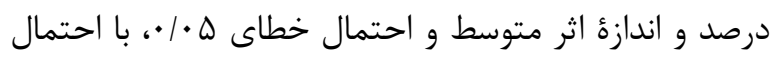

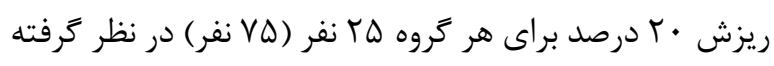

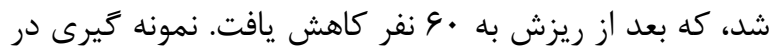

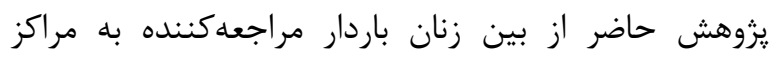

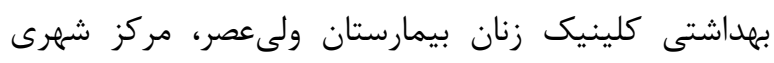
شهيد آوينى و وايخاه سفير اميد شهر بيرجند كه در سه ماءٔ

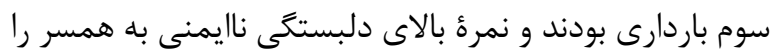

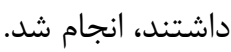

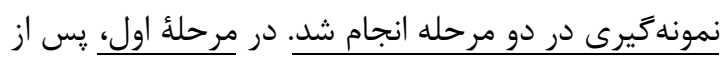

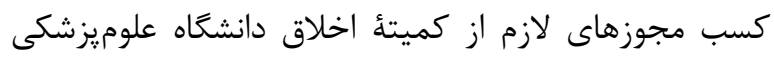

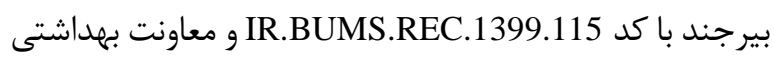
دانشخاه، يزوهشكر با مر اجعل حضورى بـ به مر اكز بهداشت مذكور، از زنان نخستزايى كه تمايل به زايمان طبيعى و شركت در دران

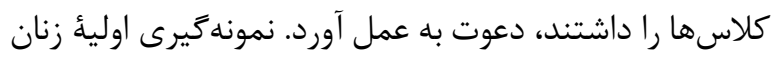

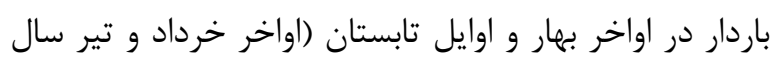

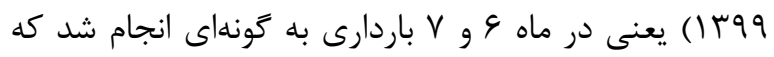

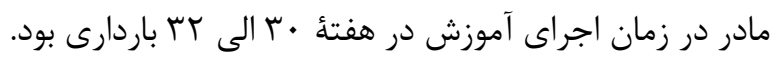

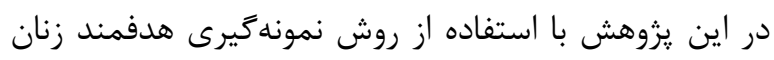

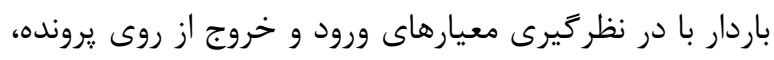

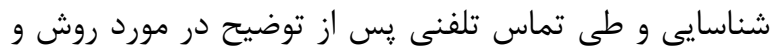

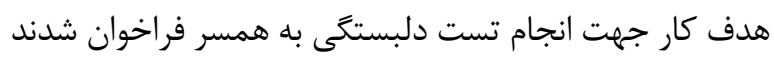

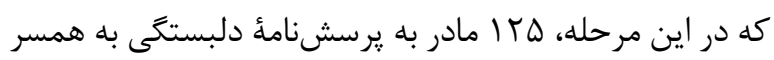

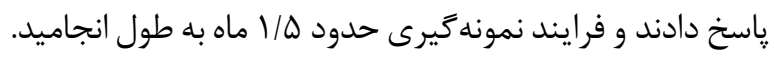
معيارهاى ورود به مطالعه شامل: فرزند اول (باردارى اول)،

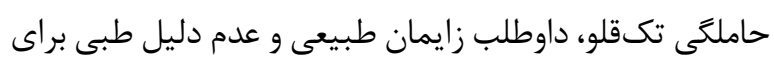

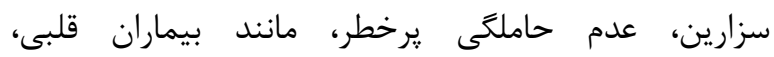

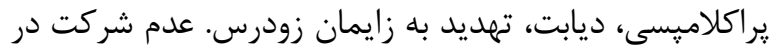

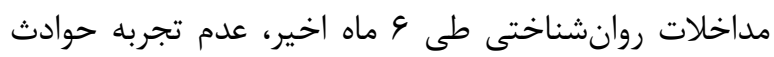

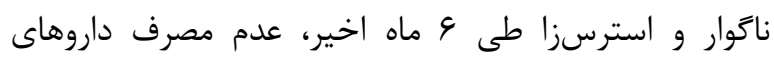

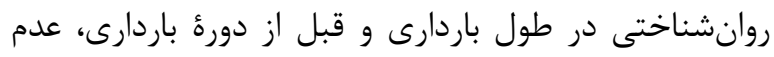

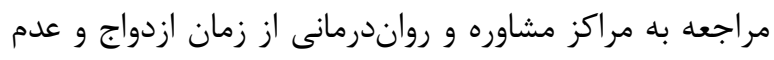

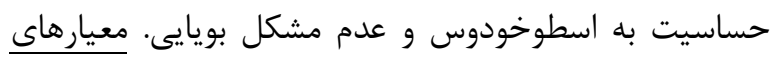


در اين : يزوهش يرسشنامهاى اطلاعات دموكرافيك،

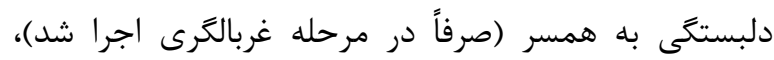

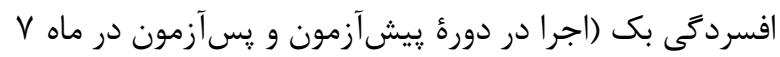

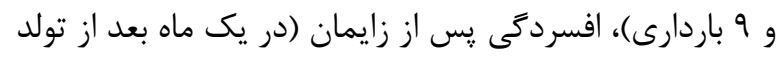
فرزند) و شايستىى مادرى (يك ماه بعد از تولد) تكميل كرديد.

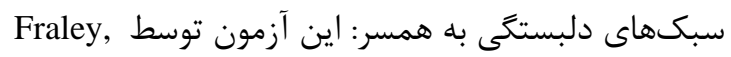
Waller \& Brennan

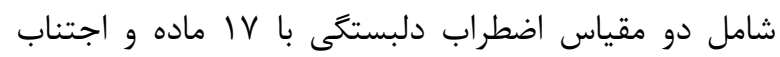

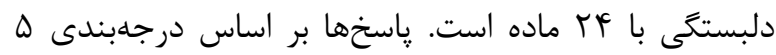

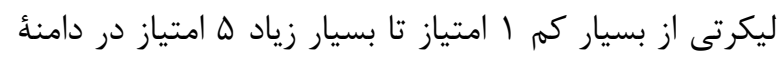

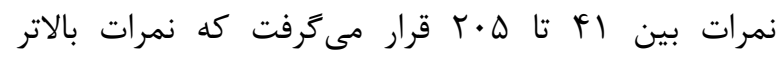

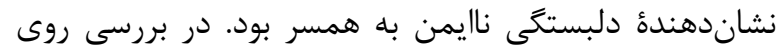

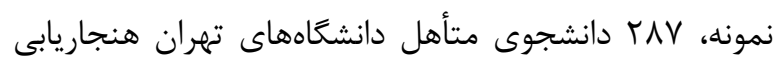

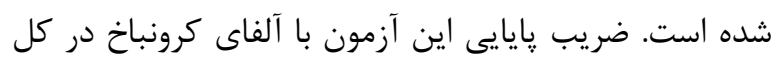

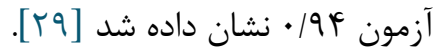

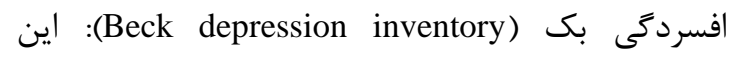
يرسشنامه سال 999 اتوسط Beck ساخته شده است. داراى

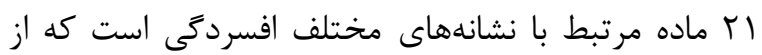

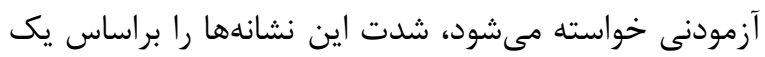

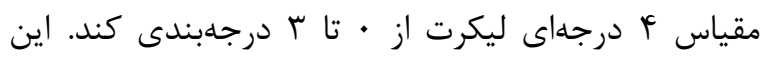

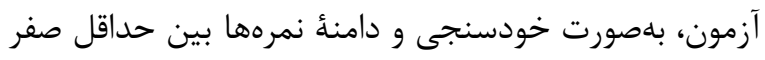

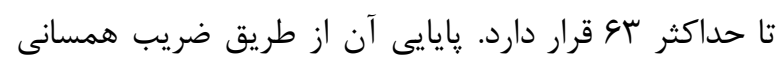

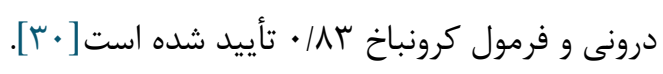

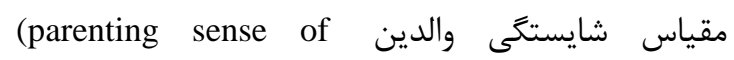
Gibaud Wallstone \& اين ابزار كه توسط

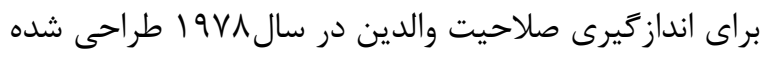

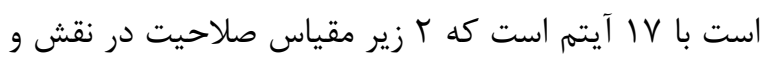

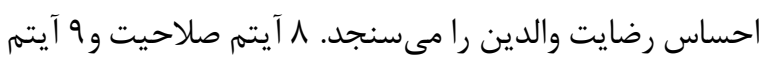

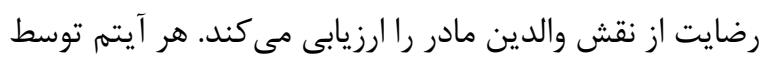

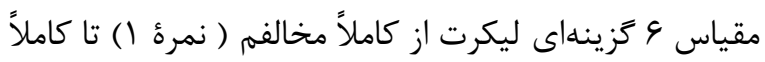

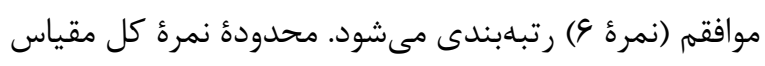

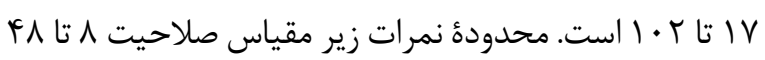

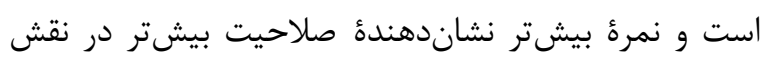

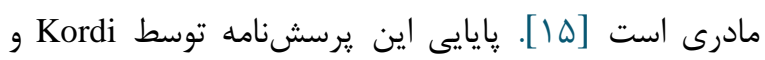

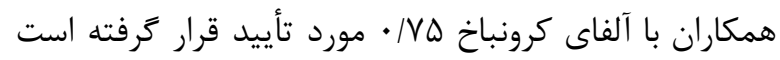

[rا

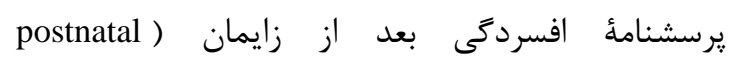

depression scale
بخور تكرار شد و بهطور ميانگَين 1 بار تكرار شد. لازم به ذكر

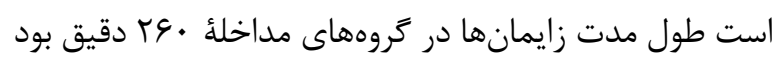

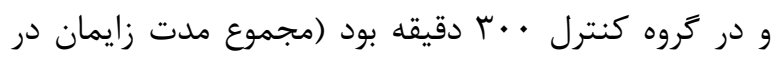

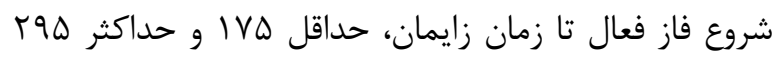

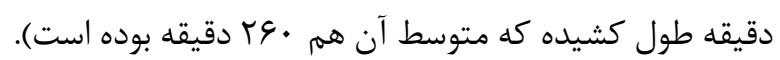

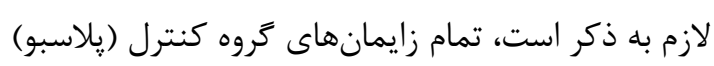

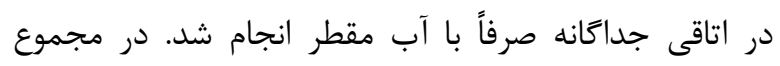

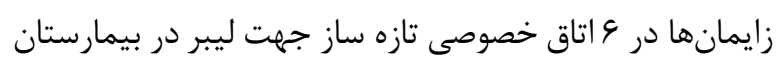

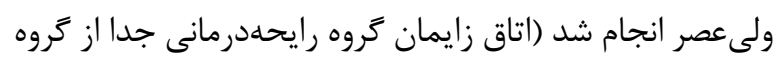

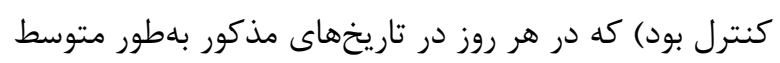

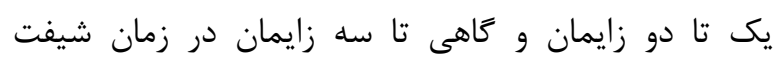

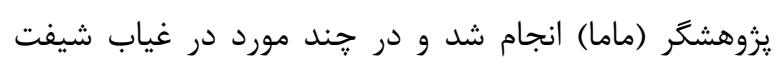

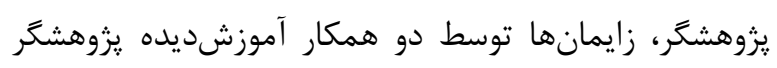

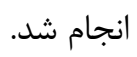

در خصوص زمان اجرا، در گروه مداخلئ اول، با توجه به

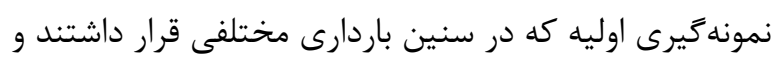

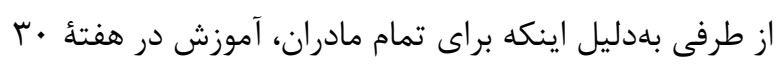

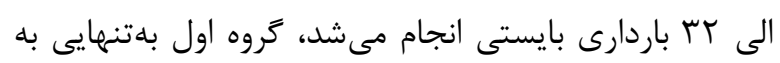

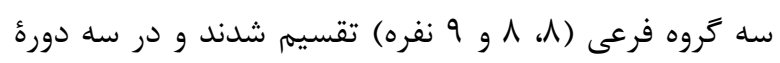

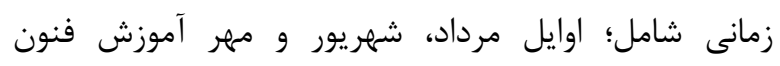
رفتاردرمانى ديالكتيكى آغاز شد.

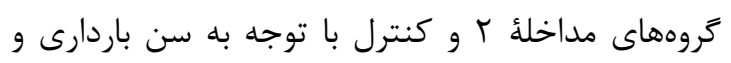

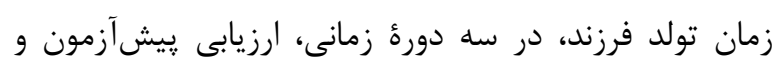

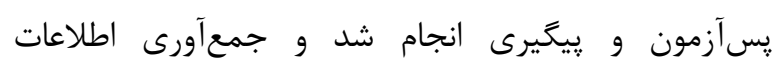

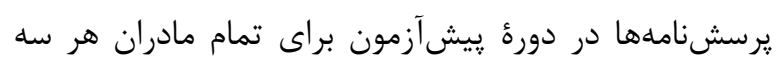

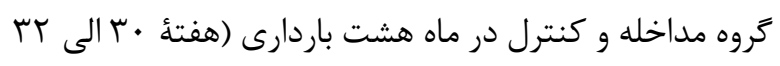

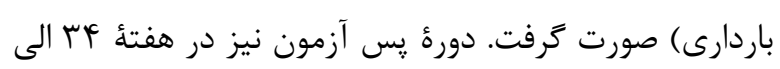

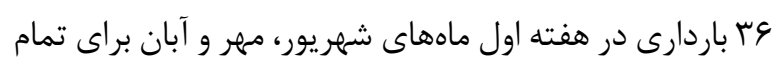

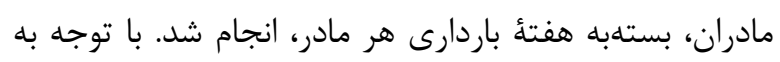

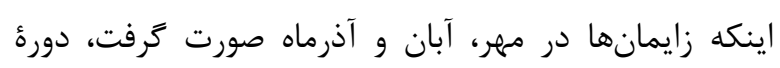

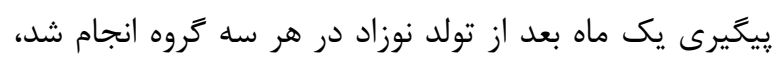

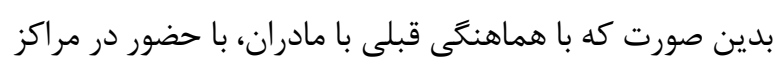

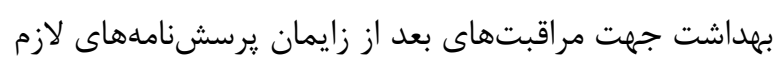

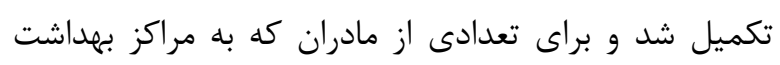

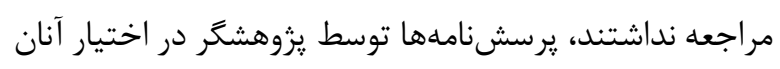
قرار ترفت.

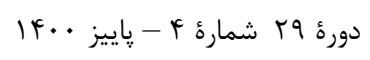


ادينبرك را ه/\%q\% و اختصاصى بودن آن را AV/9. كزارش كردند [بr]

جلسات آموزش فنون بر رفتاردرمانى ديالكتيكى بر اساس

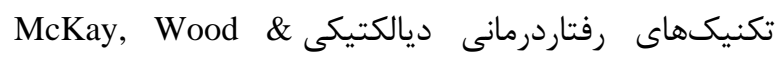
Brantley
افسردگى يّ از زايمان است كه توسط Edinburgh ساخته شده است و احساسات مادر رادر ل روز كذشته بررسى مى كند

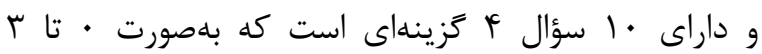

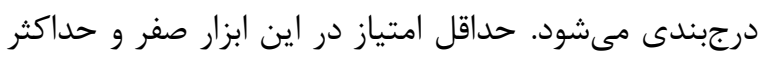

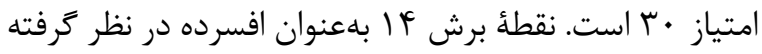

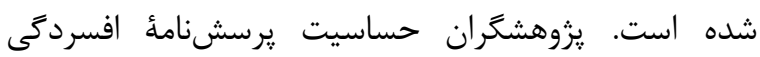

محتواى جلسات آموزش فنون رفتاردرمانى ديالكتيكى

\section{متحتوى}

جلسات

بيان قوانين و مقررات(ضمن خوشآمدكويى و سياسكزارى از آزمودنىها هدف از تشكيل جلسات آموزش، طول مدت و تعداد جلسات،

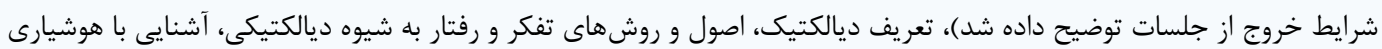
فراگير و حالات ذهنى هيجانى، خردخرا و منطقى

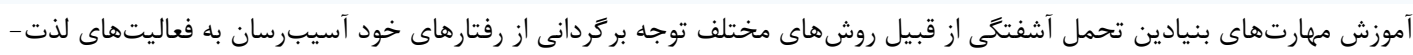

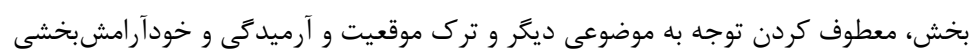

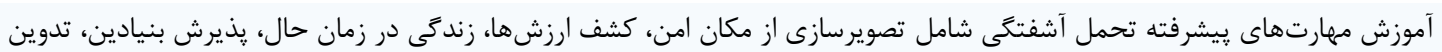

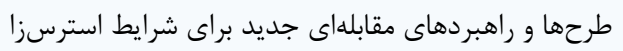

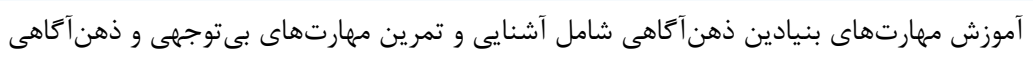

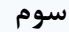

جمهارم

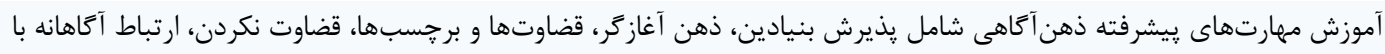

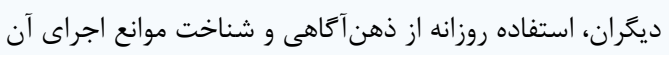

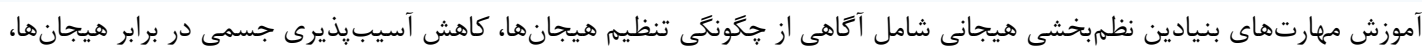

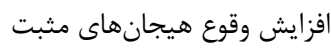

آموزش مهارتهاى يِيشرفته نظمبخشى هيجانى شامل توجه آحاهانه به هيجانات بدون قضاوت هيجانات، جحَونكى رويارويى با هيجانات

$$
\text { مثبت و منفى و حل مسأله }
$$

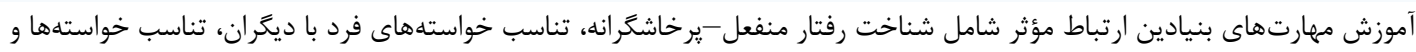

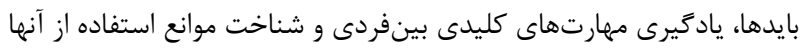

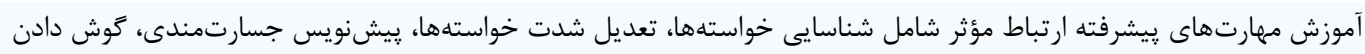

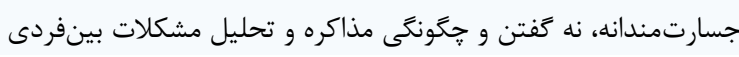

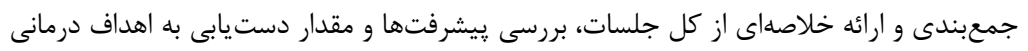

ينجم

ششم

هفتم

هشتم

نd

دهم
يزوهش به امضاى بيمار رسيد. لازم به ذكر است براى گروه

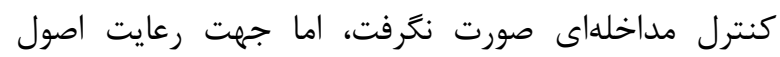
اخلاقى، دو جلسه مداخلئ آموزشى يس از دورهُ پييخيرى اجرا

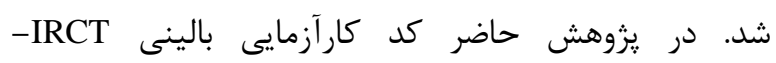

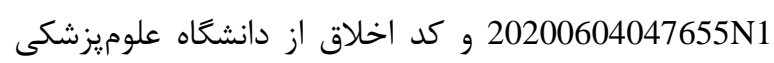
شهرستان بيرجند با شماره و و مشخصٔ UMS.REC.1399.115

بافته ها

دادههاى جمعيتشناختى سن و شغل، درامد مادر و همسر و اطلاعات مربوط به باردارى و جنين به شرح (جدول () است،
دادههاى اين يزوهش در بخش استنباطى انجام شد، افزون بر آن جهت بررسى همخنى گروهها از آزمون مجذور كاى و تحليل واريانس بهره گرفته شد. جهت تجزيهوتحليل دادهها با

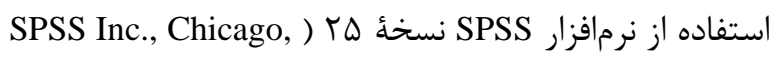

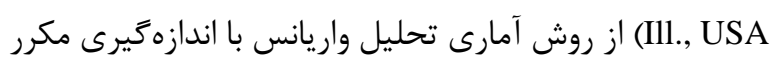
و تحليل واريانس و تحليل كوواريانس بهره گرفته شد، لازم به ذكر است قبل از هر تحليل، مفروضههاى تحليل واريانس با

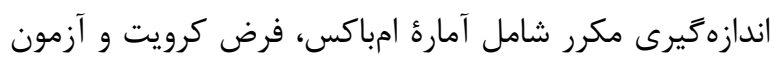
لوين بررسى و گزارش شد. لازم به ذكر است در اين مداخله، نكات اخلاقى ازجمله شركت زنان باردار با اختيار خود بود و اطلاعرسانى محرمانه

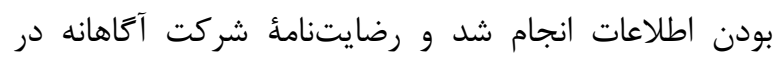

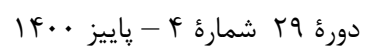

$$
\text { مجله مراقبت يرستارى و مامايى ابنسينا }
$$


نشد (ه•/P>). نتايج آزمون مجذور كاى نيز نشان داد بين كروهها از لحاظ شغل مادر و و ردر، درآمد، رضايت از جنسيت،

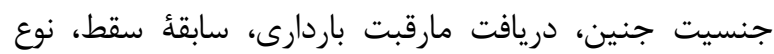
باردارى تفاوت معنى دارى وجود نداشت (ه •/P> (P).
ميانكين سنى آزمودنىهاى كروه آموزش فنون رفتاردرمانى

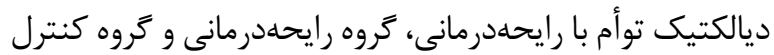

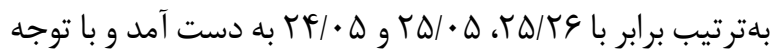
به نتايج تحليل واريانس يكراهه، تفاوت معنىدارى مشاهده

جدول (1) مقايسه فراوانى و درصد فراوانى سن، شغل، درامد و اطلاعات مربوط به باردارى و جنين

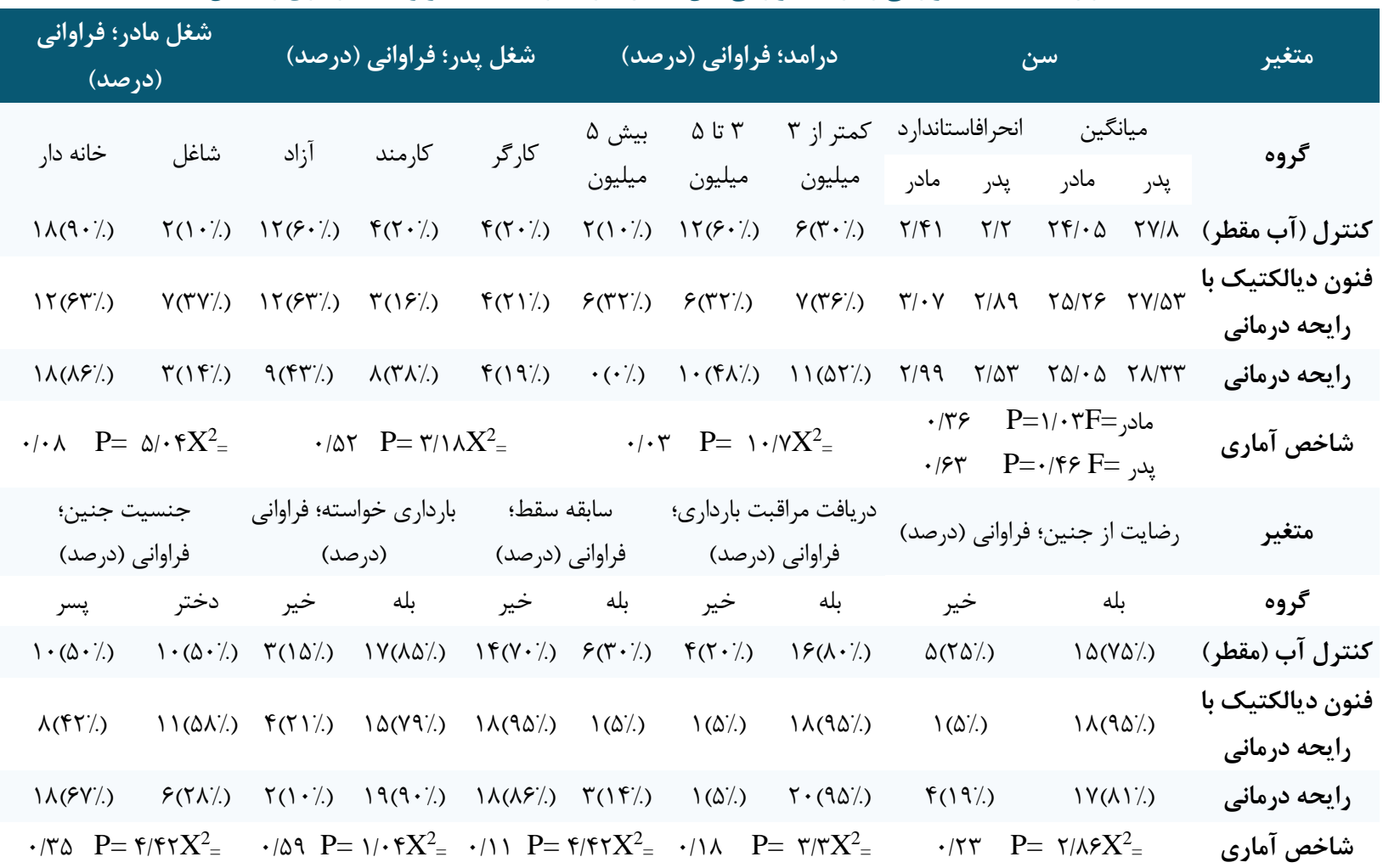

شاخصهاى توصيفى افسردكى قبل و بعد از زايمان،

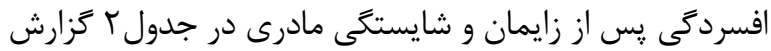

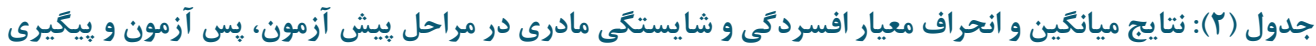

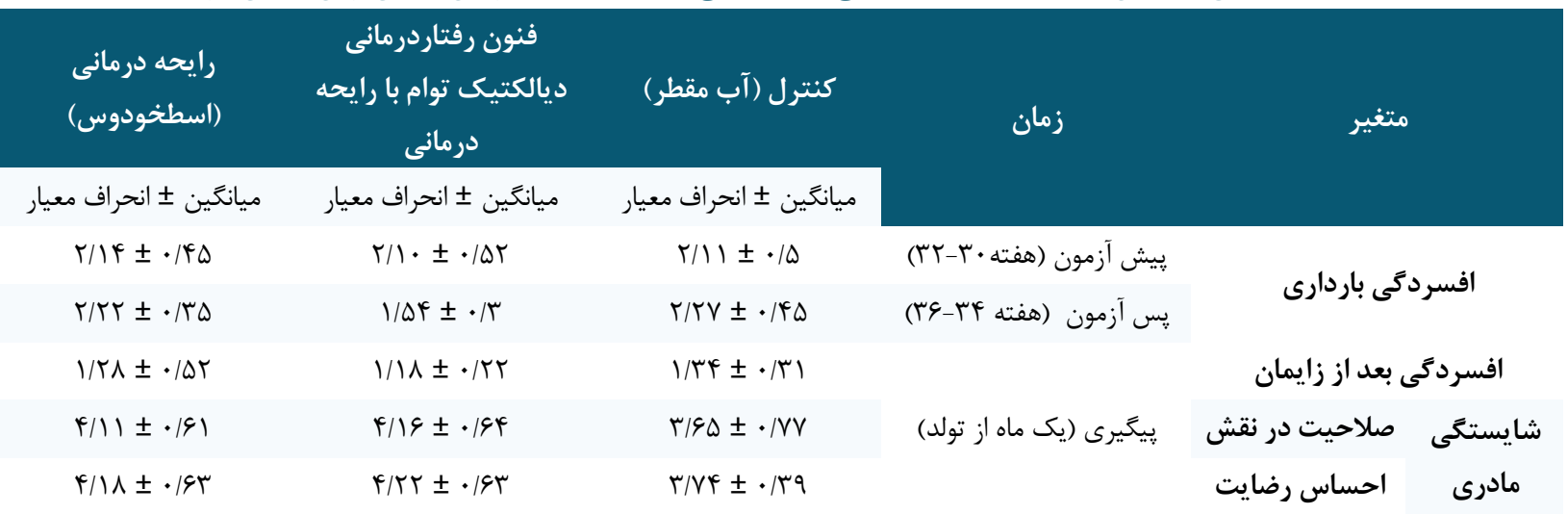


ع / • استفاده شد. همان طور كه در جدول ب مشاهده شد سطح

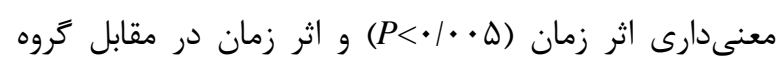

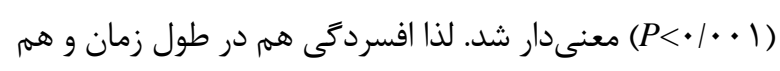

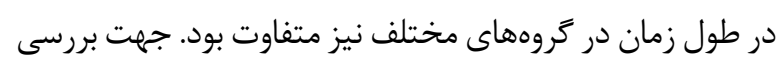

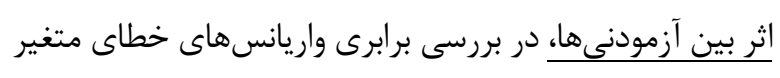

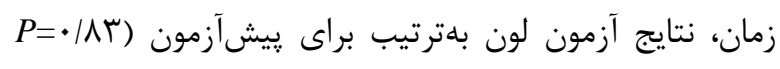

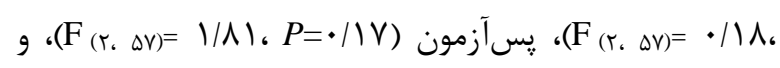

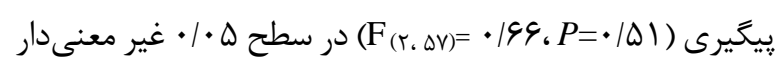

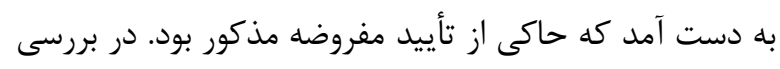

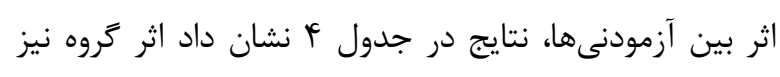
معنى دار شد.

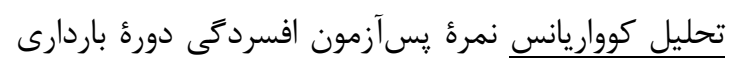

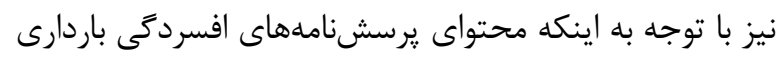

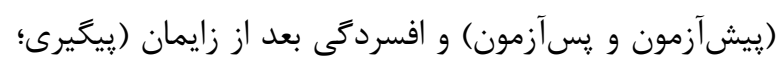

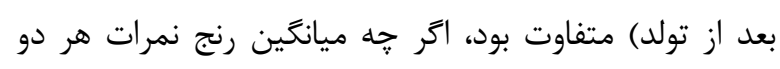

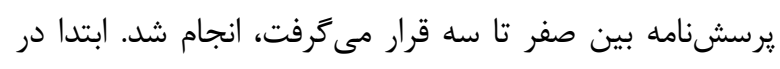

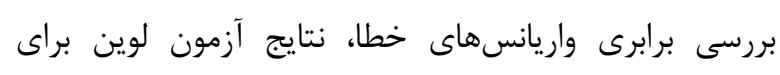

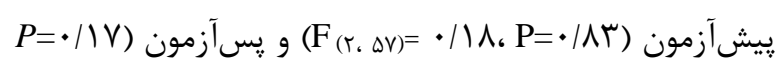

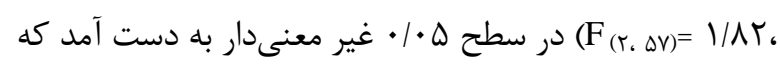

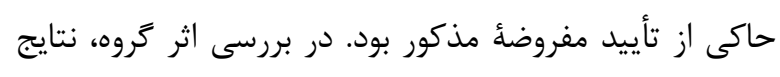
تحليل كوواريانس جدول \& أنشان داد اثر كروه معنادار بود.
تحليل واريانس اندازهخيرى مكرر افسردحى باردارى و بعد از

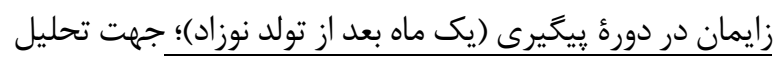

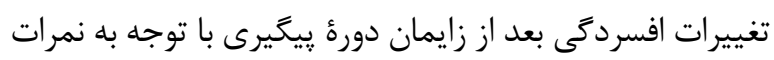

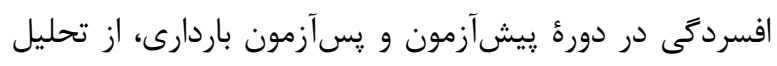

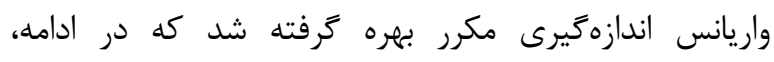

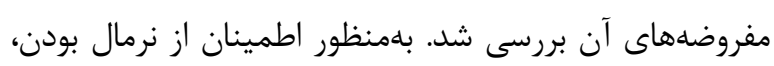

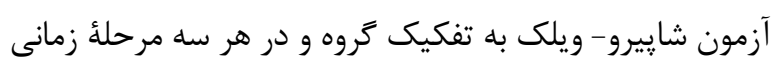

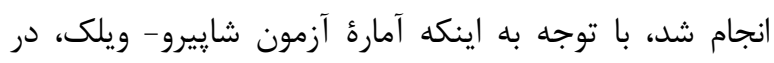

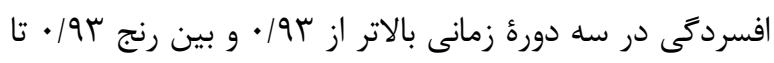

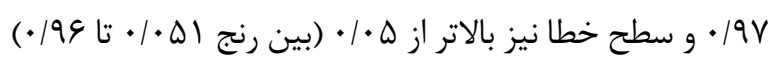

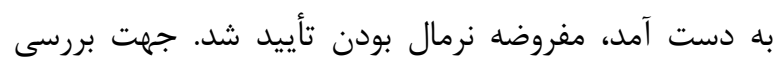

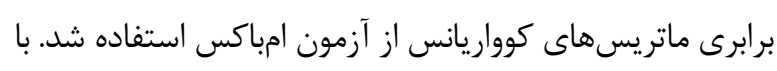

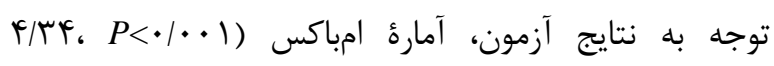

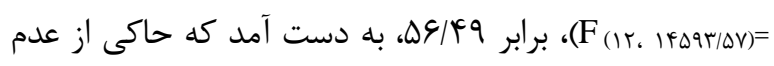
تأييد مفروضه برابرى ماتريس هاى كوواريانس بودان

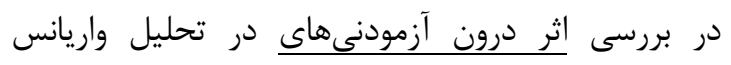

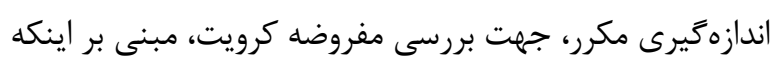

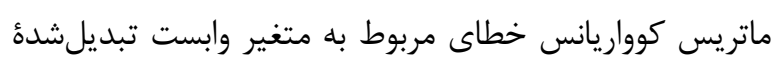

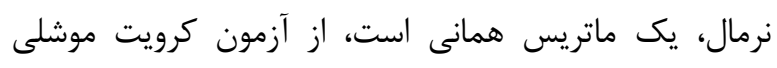

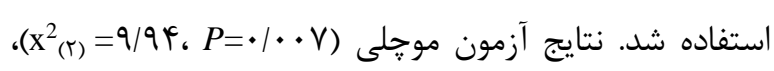

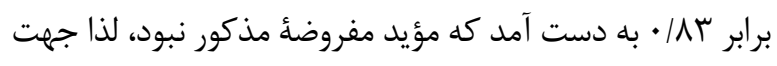

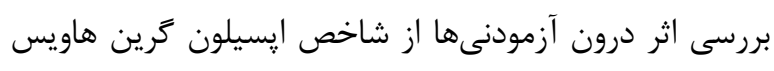

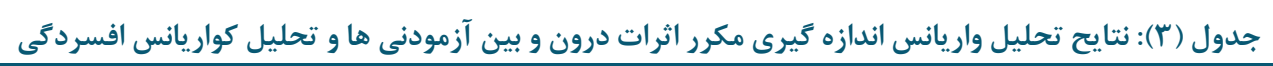

\begin{tabular}{|c|c|c|c|c|c|c|c|c|c|}
\hline مجذور اتا & P-Value & آماره F F & مربعاتين & در آزادى & مربعات نوع بم مجمع & منبع تغييرات & اثر درون و بين & روش آمارى & متغير \\
\hline$\cdot / V \cdot r$ & $\cdot 1 \cdots$ & $\mid r F / G \Lambda$ & $|r / \Delta|$ & IVT & G/r/T & زمان & & \multirow{6}{*}{\multicolumn{2}{|c|}{ 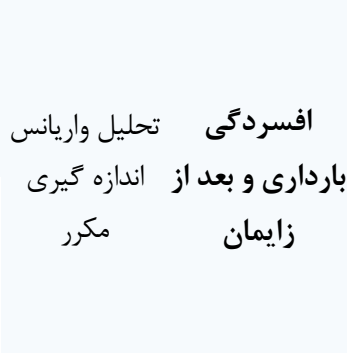 }} \\
\hline$\cdot|r \&|$ & $\cdot 1 \cdots$ & $1 \cdot 1 \cdot V$ & $1 / \cdot 1$ & $r / f y$ & $r / \uparrow q$ & زمان*گروه & & & \\
\hline & & &.$/ 1$ & $9 \Lambda / \cdot 4$ & $9 / \wedge \Lambda$ & خطا & & & \\
\hline$\cdot / 9 \mathrm{~V}$ & $\cdot 1 \cdots$ & TITQ/A| & $\Delta \wedge \vee / \mathcal{R}$. & 1 & $\Delta \wedge V / \mathcal{F}$. & عرض از مبداء & \multirow{3}{*}{ اثر بين آزمودنى } & & \\
\hline$\cdot / 11$ & r.|. & 9/9 & I/AT & r & r/gF & كروه & & & \\
\hline & & & $\cdot / T V$ & $\Delta V$ & $\mid \Delta / \& V$ & خطا & & & \\
\hline$\cdot / 4 \& V$ & $\cdot 1 \cdots$ & $p q / \cdot r$ & $r / V I$ & 1 & $r / V I$ & پيش آزمون & \multirow{3}{*}{ آزمودنى ها درون } & \multirow{3}{*}{ كوواريانس } & \multirow{3}{*}{ (بسر آزمارى آزمون) } \\
\hline \multirow[t]{2}{*}{.1090} & $\cdot 1 \cdots$ & $4 \mid / 11$ & r/. & r & $g / T \mid$ & كروه & & & \\
\hline & & & $\cdot / \cdot V$ & $\Delta \varphi$ & F/Tr & خطا & & & \\
\hline
\end{tabular}

مورد نظر از آزمون تعقيبى بنفرونى استفاده شد كه نتايج نشان

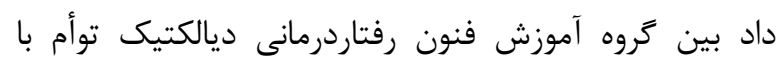

در تحليل كوواريانس افسردىى دوره باردارى، بلمنظور

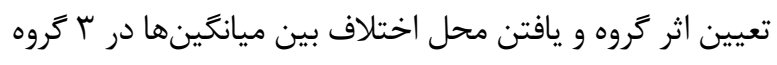


Tبها ميانگَين متغيرها به تفكيك گروههاى مورد نظر در اين ץ دوره يرداخته شد. همان طور كه (جدول عأ) نشان داد در كروه

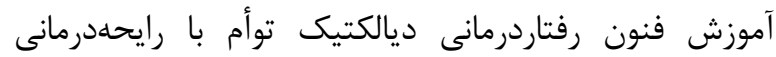

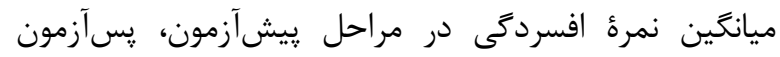
(باردارى) و يِيَيرى (بعد از تولد) يك روند كاهشى داشته است درد

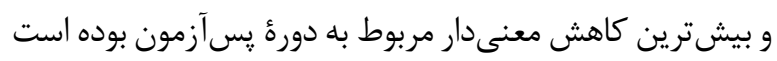

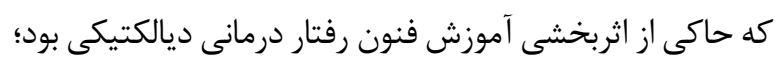

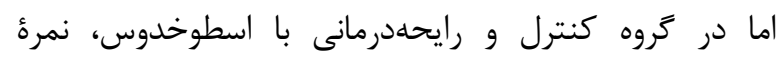

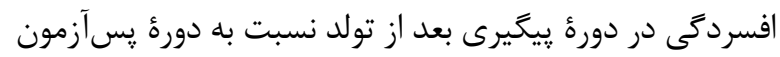

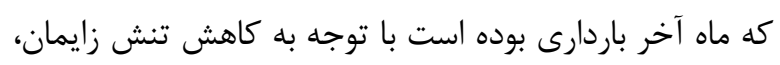

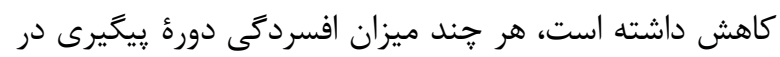

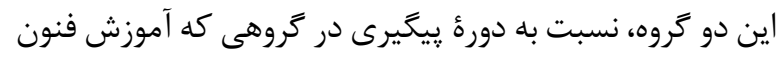

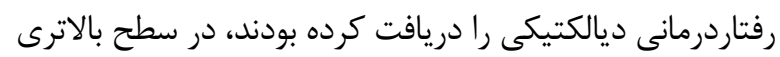

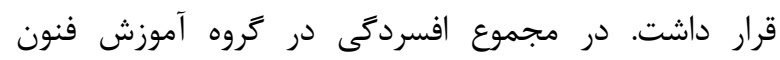

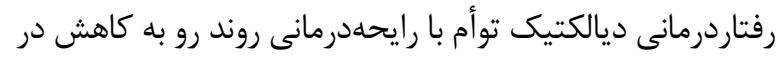
طول زمان داشته است، در صورتى كه در دو گروه ديكر در زمان باردارى روند صعودى داشته است.
رايحهدرمانى نسبت به كروه رايحهدرمانى (تفاوت

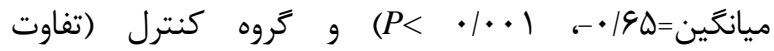

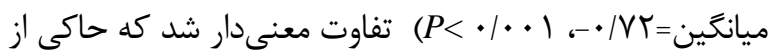

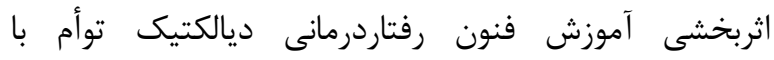
رايحهدرمانى بود. علاوه بر آن در تحليل واريانس اندازهخيرى مكرر افسردگى بودى

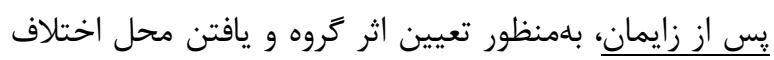

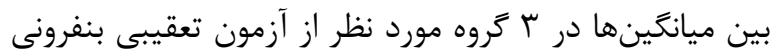

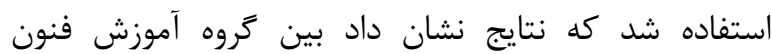

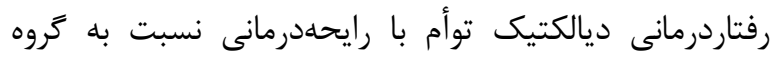

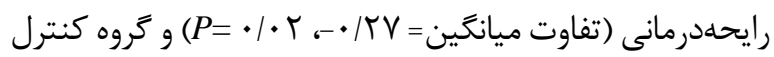

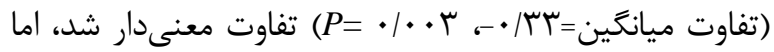
بين ميانكين كَروهاى ديكر تفاوت معنى دار نشد كه حاكى از اثربخشى آموزش فنون رفتاردرمانى ديالكتيك بود.

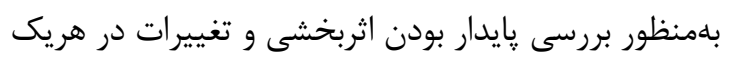

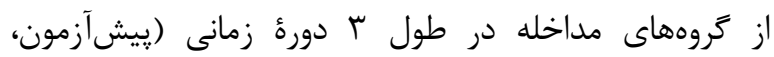

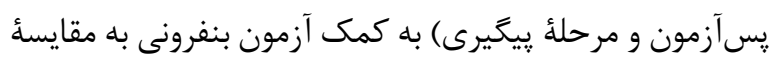

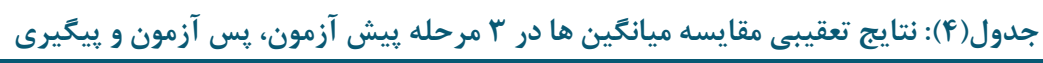

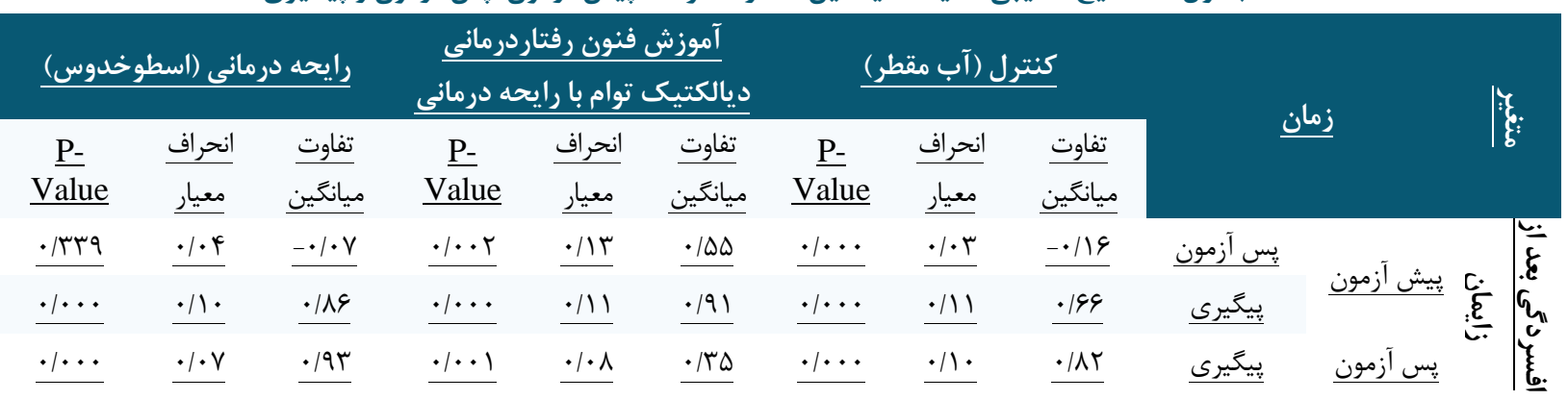

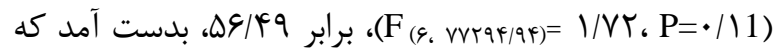
حاكى از تاييد مفروضه برابرى ماتريسهاى كواريانس بود، لذا در ،

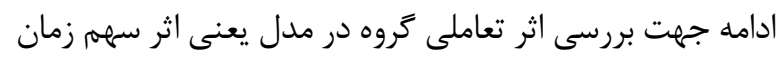

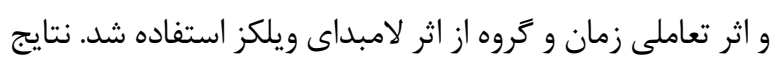
P= جند متغيره اثر لامبداى ويلكز نشان داد، اثر زمان ( P

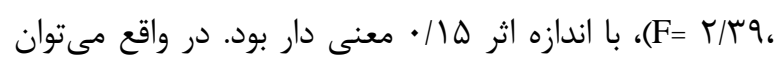
كفت حداقل يكى از مولفههاى شايستخى در طول دوره درمان

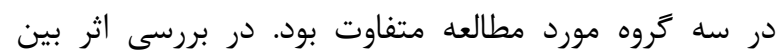

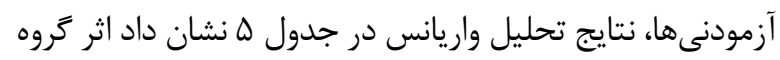
در هر r مولفه معنى دار بود.
جهت بررسى تحليل شايستخى بعد از تولد، تحليل واريانس

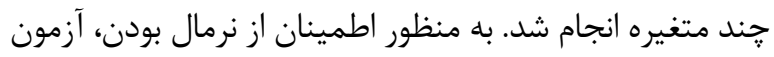
شاييرو-ويلك به تفكيك گروه در هر دو مولفه صلاحيت در نقش مئش و احساس رضايت انجام شد، با توجه به اينكه آماره آزمون شاييرو-ويلك بين رنج |9/ • تا ه9/. و سطح خطا نيز بالاتر از

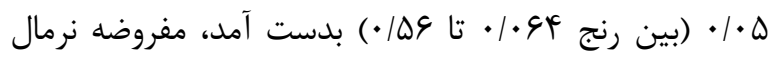
بودن تاييد شد. ابتدا در بررسى برابرى واريانسهاى خطا، نتايج

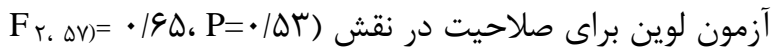

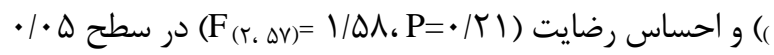
غير معنى دار بدست آمد كه حاكى از تاييد مفروضه مذكور بود.

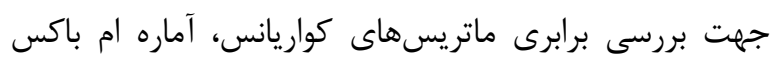


الهام ضامنى و همكاران بrץ

جدول(ه): نتايج آزمون تحليل واريانس جند متغيره شايستكى مادرى

\begin{tabular}{|c|c|c|c|c|c|c|c|}
\hline مجذور اتا & P-Value & $\mathbf{F}$ & ميانگين مربعات & درجه آزادى & مجذور مربعات & متغير وابسته & اثر \\
\hline.$/ M F$ &.$/ \cdot 1 \mathrm{~V}$ & $f / F \cdot G$ & $T / \cdot T \Lambda$ & r & $f / \cdot \Delta \Delta$ & صلاحيت در نقش & \multirow{2}{*}{ كروه } \\
\hline \multirow[t]{5}{*}{$\cdot 11 \cdot \Delta$} & $.1 \cdot$ tr & T/MFG & $1 / \cdot+\wedge$ & r & $r / .99$ & احساس رضايت & \\
\hline & & & $\cdot \mid k 9$. & $\Delta V$ & TE/TTA & صلاحيت در نقش & \multirow{2}{*}{ خطا } \\
\hline & & & rוM/. & $\Delta V$ & IVIAFq & احساس رضايت & \\
\hline & & & & 4. & १৭マ/А〉. & صلاحيت در نقش & \multirow{2}{*}{ كل } \\
\hline & & & & c. & $91 r / 090$ & احساس رضايت & \\
\hline
\end{tabular}

منجر شود. رفتاردرمانى ديالكتيك، اين دو قطب را همراه با

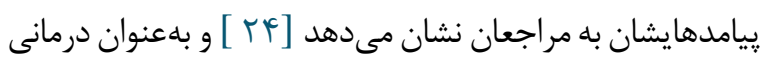
حمايت گرانه كه مستلزم ارتباطى قوى بين درمانجو و درمانگر است، مىتواند سبب رشد مهارتهايى همجِون تحمل آشفتخى، ذهن آكاهى، خودنظه جويى هيجانى و ارتباط مؤثر در مراجعان

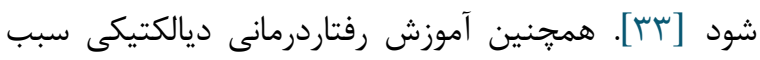
بهبود جهت فراخير در زندگى و بيرامون مىشود [YY]]. با توجه به اينكه افراد

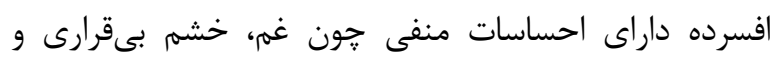
خستخى هستند، اين درمان به مادران باردار كمك مى كند تا هيجانهاى خود را دقيقتر تشخيص و هر هيجانى را بدون احساس ناتوانى بررسى كنند. به عبارتى، رفتاردرمانى ديالكتيكى هيى مادران باردار را قادر مىسازد كه ضمن درك هيجانات و ورسئ احساسات و يذيرش مشكلات و ناكارآمدىها، زندگى رانى را قابل درك و كنترليذير تصور نمايند، از اين رو افسردگى آنها كاهش ئس مىيابد. در مطالعهُ حاضر بر خلاف اثربخشى توأم بودن فنون رفتاردرمانى ديالكتيكى با رايحهدرمانى بر كاهش افسردگى، اثربخشى رايحهدرمانى نسبت به گروه كنترل بر كاهش افسردگى

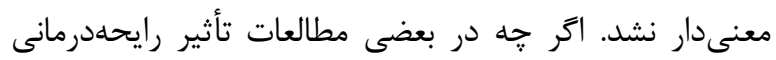
اسطوخودوس بهعنوان يك ززينهُ درمانى مؤثر براى تسكين

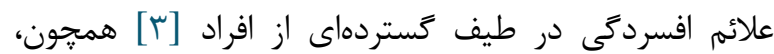

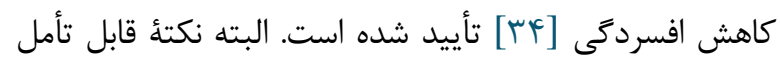
اين است كه در اين يزوهش افسردگى بلافاصله بعد از

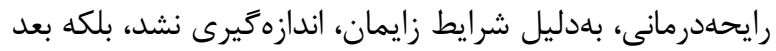

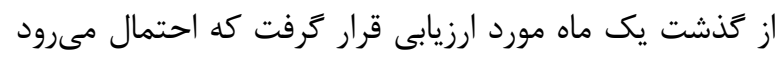
در صورت اثربخشى رايحهدرمانى، اثرات يايدارى نداشته است. به هر حال در مطالعات مذكور نيز ارزيابى كاهش افسردگى در دورٔ يِيخيرى صورت نخرفته بود.
در تحليل واريانس جند متغيره، جهت يافتن محل اختلاف بين ميانگينها در ץ گروه مورد نظر از آزمون تعقيبى بنفرونى دئى

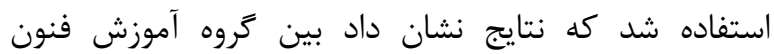
رفتاردرمانى ديالكتيك توأم با رايحهدرمانى نسبت به كروه كنترل در خصوص هر دو مولفه صلاحيت در نقش (تفاوت

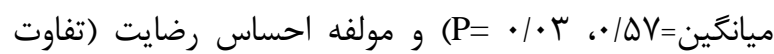

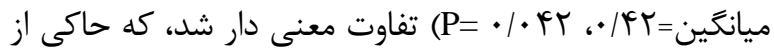

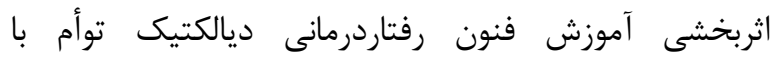
رايحهدرمانى بود. افزون بر آن نتايج نشان داد گروه رايحهدرمانى با اسطخودوس نسبت به گروه كنترل تنها در خصوص مولفه صلاحيت در نقش مادرى (تفاوت ميانخين= Pr تفاوت معنى دارى نشان داد، كه حاكى از اثربخشى رايحهدرمانى در خصوص يك مولفه بود..

\section{بحث}

نتايج نشان داد آموزش فنون رفتاردرمانى ديالكتيك در سه ماهئ آخر باردارى توأم با رايحهدرمانى فاز فعال زايمان بر بر روند روند

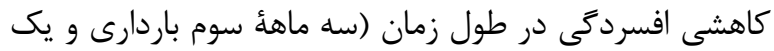

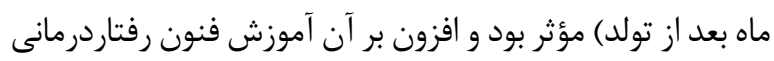

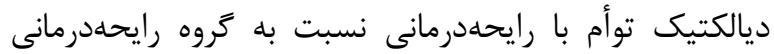
بهطور معنى دارى توانست افسردگى را كاهش دهد كه حاكى از اثربخشى آموزش فنون رفتار درمانى ديالكتيكى بود. در حمايت از يافتُ حاضر، در مطالعات متعددى اثربخشى رفتار درمانى

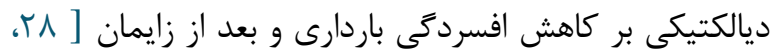

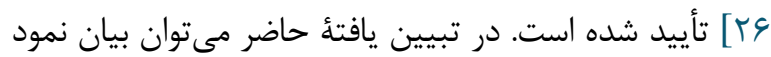

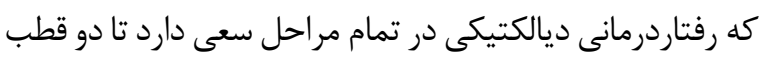

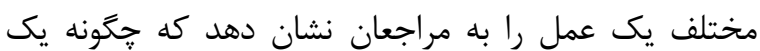
هيجان، فكر و يا رفتار مىتواند به بهبود يا تخريب يك فرآيند 
شرايط استرسزا هستند، مورد آموزش قرار گرفته است و فراتر

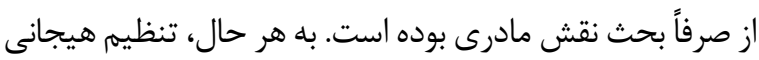
مثبت توانايى مقابله با هيجانها را در افراد ايجاد مئى كند و آنها را قادر مىسازد تا هيجانها را در خود و ديكران تشخيص دهنداندان راندان و بتوانند واكنشى مناسب در موقعيتهاى استرسزا و وادران اضطرابآور نشان دهند، به عبارتى به نظر مىرسد، راهبردهاى

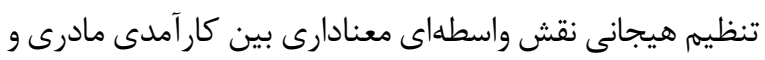
رضايت از نقش مادرى دارد و اين افراد حالتهاى مثبت و يويائي احساسات بيشترى را بروز داده، ديدگاه مثبت ترى به خود دارد دارند و بر جنبههاى مثبت محيط متمركزند، بنابراين، قابل توجيه

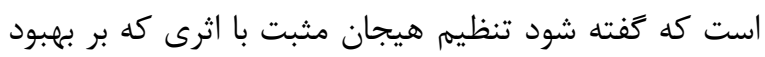
كار آمدى مادر مى كذارد، به رضايت از نقش مادرى كمك مئه مئ كند.

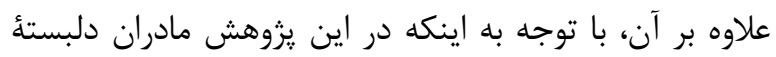

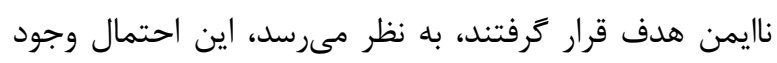
دارد كه بهدليل دلبستگى نايمن به همسر و نداشتن حمايت

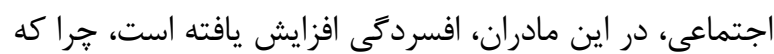

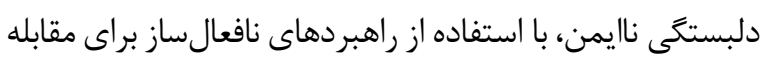
با نايمنى مى تواند تشديدكنندة افسردكى باشد [ • [1]. اما نكتئ

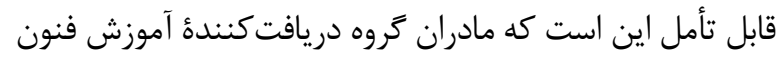

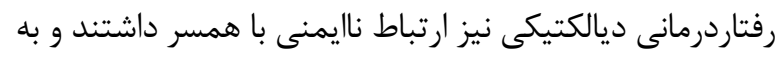

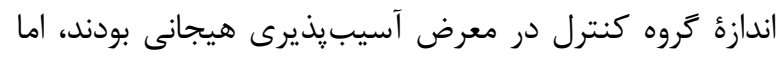
توانستند افسردگى را كاهش دهند كه اين نشاندهندة اهميت مداخلات صورت كرفته است.

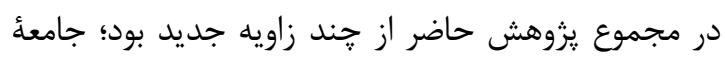

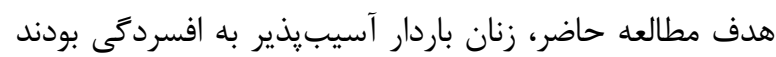

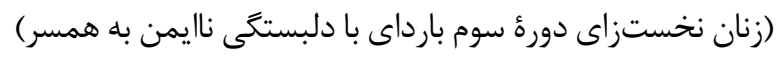

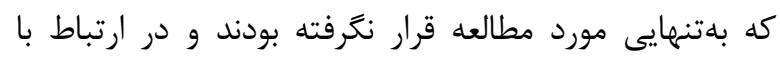
اثربخشى مداخلات مذكور نيز بررسى انجام نشده بود. نكتئ

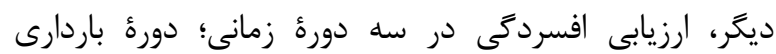

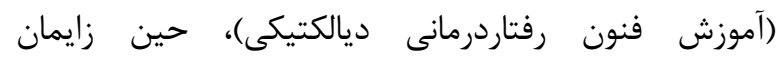

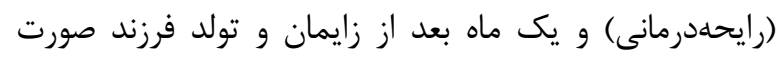

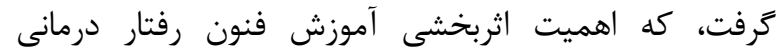

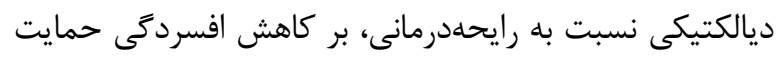

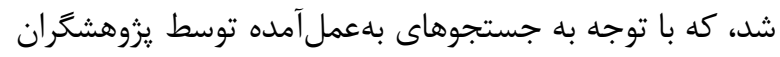

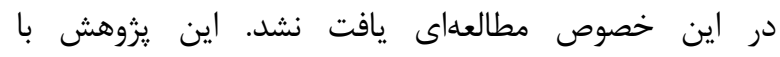
محدوديتهايى همراه بود و نكتئ قابل تأمل، كوتاه بودن دورئ

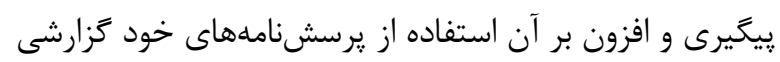
است، همجنين قابل ذكر است اين مطالعه روى زنان فاقد إندان
علاوه بر آن، نتايج نشان داد هر دو مؤلفهُ شايستگى مادرى،

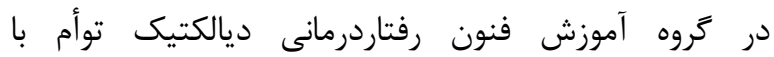
رايحهدرمانى و صلاحيت نقش در اثر كروه رايحهدرمانى بهطور

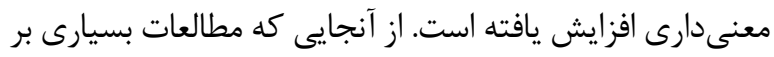

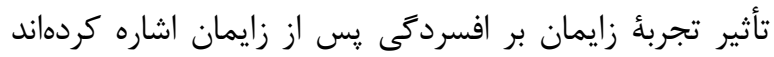

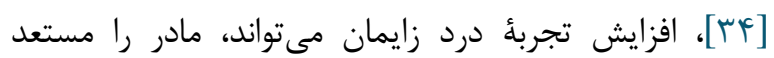

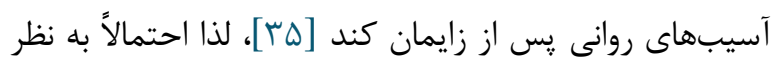
مىرسد، اثربخشى رايحهدرمانى اسطوخودوس بهدليل كاهش رانش

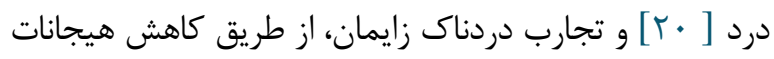

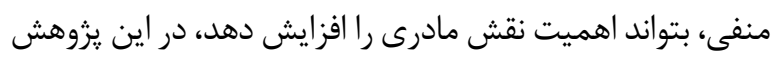

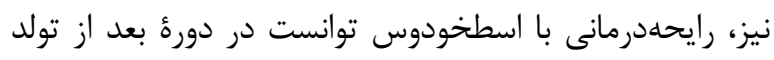

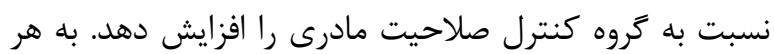

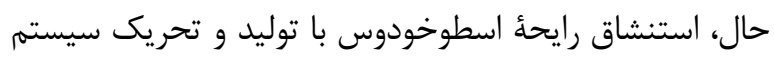

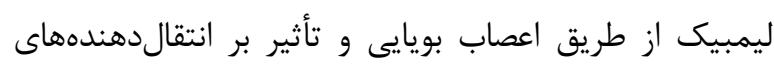

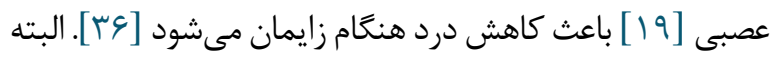

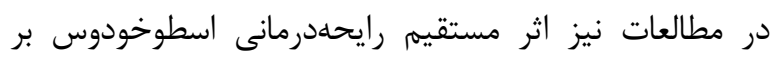

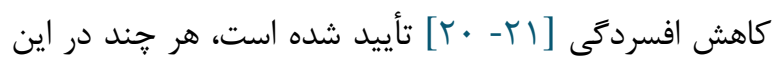

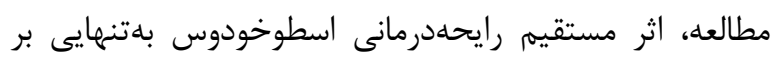

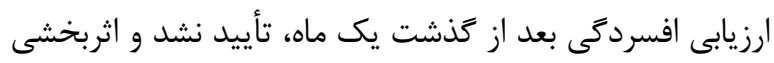

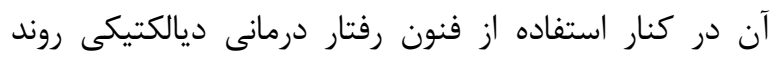

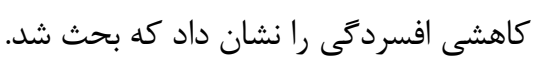

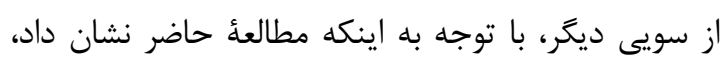

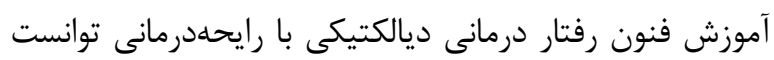

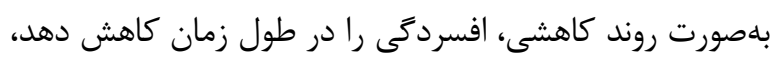

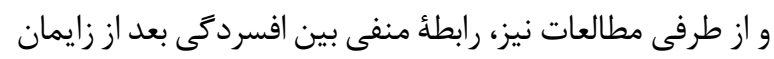

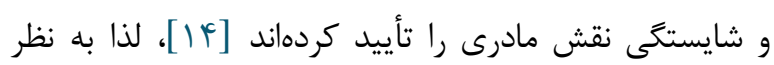

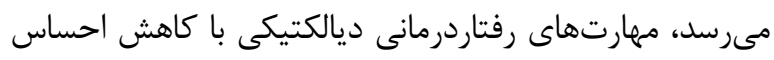

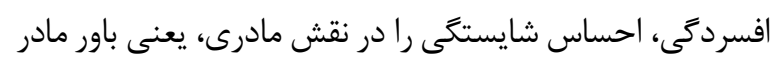

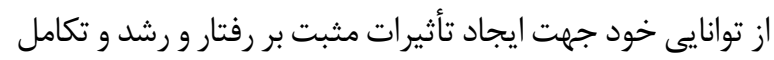

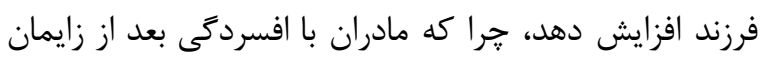

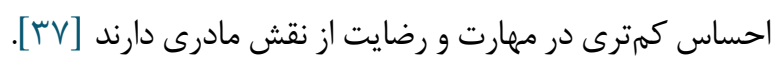

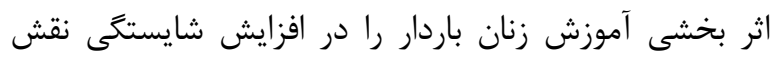

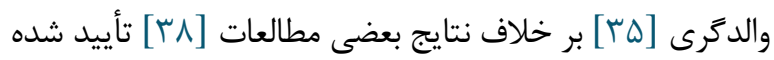

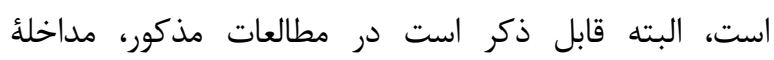

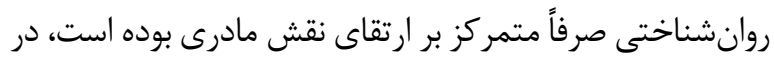

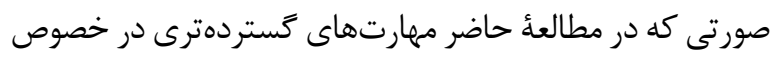

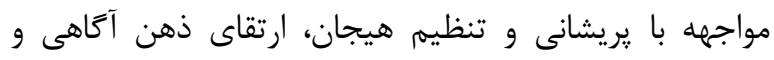

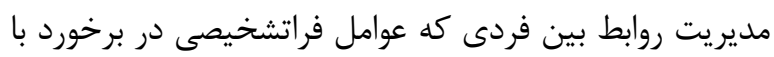

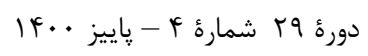


دهد. نخست زا بودن در سه ماهئ سوم باردارى و افزون بر آن دلبستخى نايمن داشتن نسبت به همسر از فاكتورهاى مستعد آسيب پيذيرى به افسردگى دوره باردارى و بعد از زايمان است.

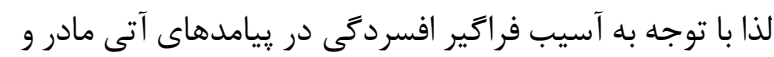
فرزند در زنان نخستزا، ييشنهاد مىشود، با شناسايى و و تشخيص زودرس مادران مستعد به اينگُونه اختلالات، با آموزش فنون رفتاردرمانى ديالكتيكى در دوره باردارى توأم با مادران

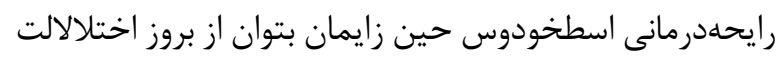
در آنها طى مراحل مختلف باردارى ييشخيرى نمود.

\section{سياسَزارى}

اين مقاله بركرفته از رساله دكترى روانشناسى بود كه در

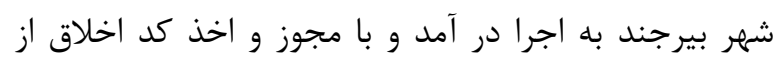

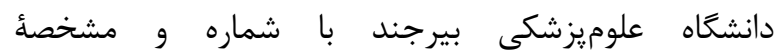
IR.BUMS.REC.1399.115 و اخذ كد كارآزمايى بالينى باه باه شماره IRCT20200604047655N1 انجام شد. نويسندكان بر خود لازم مى دانند كه از همكارى مراكز بهداشت و بيمارستان

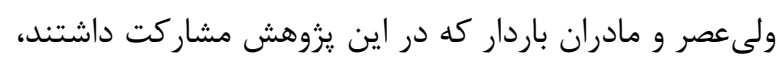
صميمانه سياسگزارى نمايند.

$$
\text { تعارض در منافع }
$$

تعارض منافع از طرف نويسندكان گزارش نشده است.

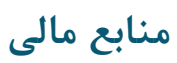

منابع مالى اين مطالعه توسط نويسندكان تأمين شده است.

\section{References}

1. Cunningham F, Leveno K, Bloom S, Dashe J, Hoffman, BL Spong CY Translated by Valdan M, Mohammadi Z. Williams obstetrics. 25 th ed; Arjmand publications; 2018:432-434.

2. Bianciardi E, Vito C, Betrò S, De Stefano A, Siracusano A, Niolu C. The anxious aspects of insecure attachment styles are associated with depression either in pregnancy or in the postpartum period. Annu Gen Psychiatry. 2020;19(1):1-9 [DOI:10.1186/s12991-02000301-7]

3. Sanchez-Vidana DI, Ngai SP, He W, Chow JK, Lau $\mathrm{BW}$, Tsang HW. The effectiveness of aromatherapy for depressive symptoms: A Systematic Review. Evid Based Complement Alternat Med. 2017; 4:1-
حاملگى گرخطر انجام گرديد. نكتهٔ قابل تأمل ديگر استفاده صرف از فنون رفتاردرمانى ديالكتيكى و انجام يس آزمون افسردگى قبل از زايمان و استفاده از اسطخودوس در بازه زمانى

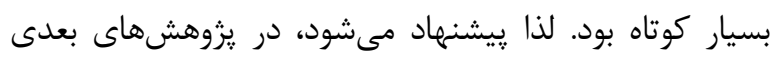

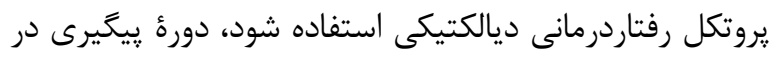

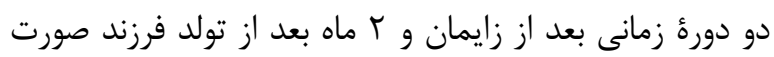
يذيرد تا امكان مقايسه روشن تر فراهم شود. افزون بر آن ييشنهاد مىشود، در مطالعات آتى، اين يزوهش در در دو گروه مادران با دلبستخى ايمن و ناايمن نيز بررسى شود. با توجه به ديه يافتهها يیشنههاد مىشود با شناسايى و تشخيص زودرس مادران

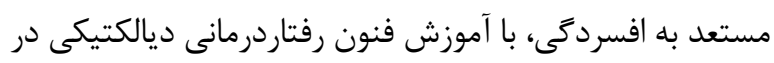

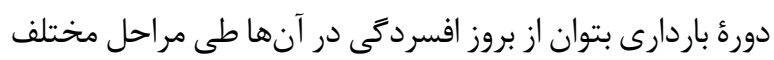

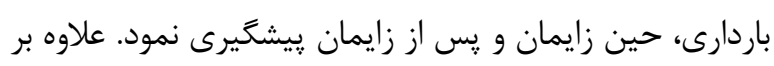
آن با توجه به اثربخشى رايحهدرمانى اسطخودودس بر شايستخى

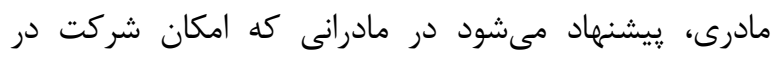
دورههاى آموزشى در زمان باردارى را ندارند، حداقل مادرانى از رايحهدرمانى اسخطودودس جهت كاهش هيحانات منغى و غم

$$
\text { و اندوه در طول زمان استفاده شود. }
$$

$$
\text { نتيجه كيرى }
$$

نتايج نشان داد آموزش فنون رفتاردرمانى ديالكتيك توأم با رايحهدرمانى بر كاهش افسردگى زنان نخست زا با سبك

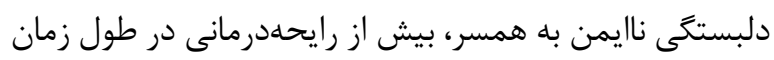

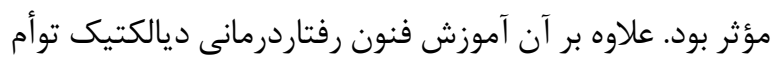

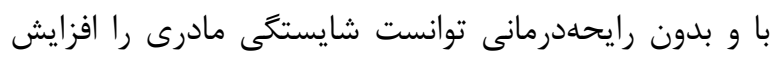

\section{1:e5869315. [DOI:10.1155/2017/5869315] [PMID] [PMCID]}

4. Prelog PR, Makovec MR, Šimic MV, Sršen TP, Perat M. Individual and contextual factors of nulliparas' levels of depression, anxiety and fear of childbirth in the last trimester of pregnancy: intimate partner attachment a key factor? Zdr Varst. 2019;58(3):112-9. [DOI:10.2478/sjph-2019-0015] [PMID] [PMCID]

5. Bright KS, Mughal MK, Wajid A, Lane-Smith M, Murray L, Roy N, et al. Internet-based interpersonal psychotherapy for stress, anxiety, and depression in prenatal women: study protocol for a pilot randomized controlled trial. Trials. 2019;20(1):1-11 [DOI:10.1186/s13063-019-3897-z] [PMID] [PMCID]

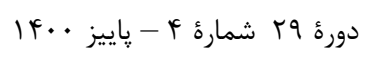

$$
\text { مجله مراقبت يُرستارى و مامايى ابنسينا }
$$


6. Tokumitsu K, Sugawara N, Maruo K, Suzuki T, Shimoda K, Yasui-Furukori N. Prevalence of perinatal depression among Japanese women: a meta-analysis. Ann Gen Psychiatry. 2020; 19(1):1-18. [DOI:10.1186/s12991-020-00316-0] [PMID] [PMCID]

7. Manavipour D, Heidari S. Effectiveness of education on stress relief based on conscientiousness on resiliency, emotional regulation and attachment styles in men. J Analitical-Cogn Psychol. 2018; 9(34):55-67. [http://www.iaujournals.ir/article_664603_ab03619c91 8ad903559f87e8c85792f0.pdf]

8. Sutton TE. Review of attachment theory: Familial predictors, continuity and change, and intrapersonal and relational outcomes. Marriage Fam Rev. 2019;55(1):122 [DOI:10.1080/01494929.2018.1458001]

9. Nilforooshan P, Navidian A. Composition of spouses' attachment dimensions on marital satisfaction. J Fund Ment Health. 2014;16(63):200-12.

10. Falgares G, Lo Gioco A, Verrocchio MC, Marchetti D. Anxiety and depression among adult amputees: the role of attachment insecurity, coping strategies and social support. Psychol Health Med. 2019;24(3):281-93. [DOI:10.1080/13548506.2018.1529324] [PMID]

11. Chae J-Y. The influence of pregnant couples' attachment representation for parents of origin on their psychological symptoms. Fam Environ Res. 2019;57(1):41-50. [DOI:10.6115/fer.2019.004]

12. Røhder K, Væver MS, Aarestrup AK, Jacobsen RK, Smith-Nielsen J, Schiøtz ML. Maternal-fetal bonding among pregnant women at psychosocial risk: The roles of adult attachment style, prenatal parental reflective functioning, and depressive symptoms. PloS one. 2020;15(9):e0239208. [PMID] [PMCID] [DOI:10.1371/journal.pone.0239208]

13. Knoche LL, Givens JE, Sheridan SM. Risk and protective factors for children of adolescents: Maternal depression and parental sense of competence. J Child Fam Stud. 2007 Oct 1;16(5):684-95. [DOI:10.1007/s10826-006-9116-Z]

14. Gao L-l, Chan SW-c, Sun K. Effects of an interpersonal-psychotherapy-oriented childbirth education programme for Chinese first-time childbearing women at 3-month follow up: randomised controlled trial. Int J Nurs Stud. 2012;49(3):274-81. [DOI:10.1016/j.ijnurstu.2011.09.010] [PMID]

15. Jahdi F, Kaheh A, Haghani H. Effect of attachment behaviors training on maternal competence attainment in nulliparous adolescent women. J Babol Univ Med Sci. 2019;21(1):78-84.

16. Vakilian K, Karamat A, Mousavi A, Shariati M, Ajami E, Atarha M. The effect of Lavender essence via inhalation method on labor pain. J Shahrekord Univ Med Sci. 2012; 14:34-40. [http://78.39.35.44/article-11049-en.html]

17. Łyczko J, Jałoszyński K, Surma M, García-Garví JM, Carbonell-Barrachina ÁA, Szumny A. Determination of various drying methods' impact on odour quality of true lavender (lavandula angustifolia Mill. Flowers.
Molecules. 2019; 24(16):1-15.290.

[DOI: 10.3390/molecules24162900] [PMID] [PMCID]

18. Mohammadi MM, Parandin S. Effect of the combination of Benson's relaxation technique and brief psychoeducational intervention on multidimensional pain and negative psychological symptoms of pregnant women: A randomized controlled trial. J Educ Health Promot. 2019;8(1):1-7.

19. Zamanifar S, Bagheri-Saveh MI, Nezakati A, Mohammadi R, Seidi J. The effect of music therapy and aromatherapy with chamomile-lavender essential oil on the anxiety of clinical nurses: A randomized and double-blind clinical trial. J Med Life. 2020; 13(1):8793.

20. Jafari-Koulaee A, Khenarinezhad F, Sharifi Razavi A, Bagheri-Nesami M. The effect of aromatherapy with lavender essence on depression and headache disability in migraine patients: A randomized clinical trial. J Med Plants. 2019; 18(70):162-72. [http://jmp.ir/article-12571-en.html] [DOI:10.29252/jmp.2.70.162]

21. Xiong M, Li Y, Tang P, Zhang Y, Cao M, Ni J, et al. Effectiveness of aromatherapy massage and inhalation on symptoms of depression in Chinese communitydwelling older adults. J Altern Complement Med. 2018; 24(7):717-24. [DOI:10.1089/acm.2017.0320] [PMID]

22. Evin A, Khojasteh F, Ansari H. The Effect of Hatha Yoga on Anxiety and Self-Efficacy of Primiparous Women in Labor. Open Complement Med J. 2019;9(1):3546-59.

23. Cannon JL, Umstead LK. Applying dialectical behavior therapy to self-harm in college-age men: A case study. J Coll Couns 2018; 21(1):87-96. [magiran.com/ p1995119] [DOI:10.1002/jocc.12089]

24. DeCou CR, Comtois KA, Landes SJ. Dialectical behavior therapy is effective for the treatment of suicidal behavior: A meta-analysis. Behav Ther. 2019; 50(1):60-72. [DOI:10.1016/j.beth.2018.03.009] [PMID]

25. Eisner L, Eddie D, Harley R, Jacobo M, Nierenberg AA, Deckersbach T. Dialectical behavior therapy group skills training for bipolar disorder. Behav Ther. 2017; 48(4):557-66. [DOI:10.1016/j.beth.2016.12.006] [PMID] [PMCID]

26. Huang J-W, Zhou X-Y, Lu S-J, Xu Y, Hu J-B, Huang $\mathrm{M}-\mathrm{L}$, et al. Dialectical behavior therapy-based psychological intervention for woman in late pregnancy and early postpartum suffering from COVID-19: a case report. J Zhejiang Univ Sci B. 2020; 21(5):394-9. [DOI:10.1631/jzus.B2010012] [PMID] [PMCID]

27. Miri N, Nayyeri M. Comparison the effectiveness of dialectical behavior therapy, drug therapy and their combination methods on depression and Irrational Beliefs in women with postpartum depression. Iran $\mathbf{J}$ Psy Nurs. 2019;7(2):1-9.

28. Bahrami M, Bakhtiari N, Haji Z, Fathi Z. The effectiveness of dialectical behavioral therapy on GAD incidence and Substance Abuse. J Motor Behav Sci 2018;1(3):203-10.

[http://www.jmbs.ir/article_87591_en.html?lang=fa]

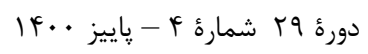

$$
\text { مجله مراقبت يرستارى و مامايى ابنسينا }
$$


29. Sarmad Z, Bazargan A, Hejazi E. Research methods in behavioral sciences. Tehran. Agah publications; 2007.

30. Safaralinezhad A, Oveisi S, Sarichlu Me, Jourabchi Z. Effect of cognitive-behavioral group therapy on gestational depression: A clinical trial. Iran J Obstet Gynecol Infertilit. 2018; 21(2):48-59. [http://ijogi.mums.ac.ir/article_10712.html]

31. Kordi M, Fasanghari M, Asgharipour N, Esmaily H. The effect of maternal role training program on role attainment and maternal role satisfaction in nulliparous women with unplanned pregnancy. J Educ Health Promot. 2017;6. 113-115. [DOI:10.4103\%2Fjehp.jehp 113 15]

32. Ghanbarzadeh N, Mehrani Z, Sharifzadeh G, NadjafiSemnani A, Nadjafi-Semnani M. Investigation the relationship between moral intelligence, social adjustment, and postpartum depression in women referring to Birjand health centers. EBNESINA 2020; 21(4):100-4. [http://ebnesina.ajaums.ac.ir/article-1870-en.html]

33. Robinson S, Lang JE, Hernandez AM, Holz T, Cameron M, Brannon B. Outcomes of dialectical behavior therapy administered by an interdisciplinary team. Arch Psychiatr Nurs 2018; 32(4):512-516. [DOI:10.1016/j.apnu.2018.02.009] [PMID]

34. Muchanga SMJ, Yasumitsu-Lovell K, Eitoku M, Mbelambela EP, Ninomiya $\mathrm{H}$, Komori $\mathrm{K}$, et al. Preconception gynecological risk factors of postpartum depression among Japanese women: The Japan Environment and Children's Study (JECS). J Affect Disord. 2017;217:34-41. [DOI:10.1016/i.jad.2017.03.049] [PMID]

35. Kordi M, Bakhshi M, Masoudi S, Esmaily H. Effect of prenatal psychological trainings on satisfaction with childbirth and maternal role competence in primiparous women. J Maz Uni Med Sci. 2018; 28(165):98-108. [http://jmums.mazums.ac.ir/article-1-10865-en.html]

36. Kazeminia M, Abdi A, Vaisi-Raygani A, Jalali R, Shohaimi S, Daneshkhah A, et al. The effect of lavender (Lavandula stoechas L.) on reducing labor pain: A systematic review and meta-analysis. Evid Based Complement Alternat Med. 2020;1-11:e4384350. [DOI:10.1155/2020/4384350] [PMID] [PMCID]

37. Chung F-F, Wan G-H, Kuo S-C, Lin K-C, Liu H-E. Mother-infant interaction quality and sense of parenting competence at six months postpartum for first-time mothers in Taiwan: a multiple time series design. BMC Pregnancy Childbirth. 2018; 18(1):1-13 [DOI:10.1186/s12884-018-1979-7] [PMID] [PMCID]

38. Abdollahpour N, Seyedfatemi N, HakimShooshtari M, Mehran A. The effect of education on sense of competence of mothers of children with hyperactivity disorder. J Nurs Educ 2017; 5(4):19-26. [http://ijpn.ir/article-1-901-en.html] [DOI:10.21859/ijpn-05043] 